\title{
The Neodymium Stable Isotope
} Composition of the Oceanic Crust: Reconciling the Mismatch Between Erupted Mid-Ocean Ridge Basalts and Lower Crustal Gabbros

\author{
Alex J. McCoy-West ${ }^{1,2 *}$, Marc-Alban Millet ${ }^{3}$ and Kevin W. Burton ${ }^{2}$ \\ ${ }^{1}$ School of Earth, Atmosphere and Environment, Monash University, Clayton, VIC, Australia, ${ }^{2}$ Department of Earth Sciences, \\ Durham University, Durham, United Kingdom, ${ }^{3}$ School of Earth and Ocean Sciences, Cardiff University, Cardiff, \\ United Kingdom
}

OPEN ACCESS

Edited by:

Fang-Zhen Teng,

University of Washington,

United States

Reviewed by:

Gangjian Wei,

Guangzhou Institute of Geochemistry

(CAS), China

Shui Jiong Wang,

China University of Geosciences,

China

*Correspondence:

Alex J. McCoy-West

alex.mccoywest@monash.edu;

alex.mccoywest@gmail.com

Specialty section:

This article was submitted to

Geochemistry,

a section of the journal

Frontiers in Earth Science

Received: 12 September 2019

Accepted: 24 January 2020

Published: 19 February 2020

Citation:

McCoy-West AJ, Millet M-A and Burton KW (2020) The Neodymium Stable Isotope Composition of the

Oceanic Crust: Reconciling

the Mismatch Between Erupted Mid-Ocean Ridge Basalts and Lower

Crustal Gabbros.

Front. Earth Sci. 8:25.

doi: 10.3389/feart.2020.00025
The trace element and isotopic compositions of mid-ocean ridge basalts (MORB) provide an important cornerstone for all studies seeking to understand mantle evolution. Globally there is a significant over-enrichment in the incompatible trace element concentrations of MORB relative to levels which should be generated by fractional crystallization. Thermal and geochemical constraints suggest that MORB require generation in open system magma chambers. However, the petrology of lower oceanic crustal rocks suggests instead that these enrichments maybe formed through reactive porous flow (RPF). Stable isotope compositions are process dependent and therefore provide an excellent mechanism to compare these contrasting models. This study presents the first neodymium ( $\mathrm{Nd}$ ) stable isotope compositions of Indian MORB and well characterized gabbroic rocks from the lower oceanic crust sampled at the Southwest Indian Ridge (SWIR) (Hole 735B). Indian MORB is extremely homogenous with a mean $\delta^{146} \mathrm{Nd}$ of $-0.025 \pm 0.005 \%$ which is identical to the composition of Pacific MORB. Despite significant variability in the source composition of MORB globally (i.e., ${ }^{143} \mathrm{Nd} /{ }^{144} \mathrm{Nd}$ ) their indistinguishable $\delta^{146} \mathrm{Nd}$ compositions suggests $\delta^{146} \mathrm{Nd}$ was homogenized through a consistent process (i.e., repeated melt addition in the open-system magma chambers across the global ridge network). In stark contrast, oceanic gabbros have $\delta^{146} \mathrm{Nd}$ ranging from -0.026 to $-0.127 \%$, doubling the natural variability in $\mathrm{Nd}$ stable isotopes observed in terrestrial rocks. Clinopyroxene separates possess variable $\delta^{146} \mathrm{Nd}$ but are isotopically heavier than the gabbroic whole rocks at the same major element compositions. These large variations in $\delta^{146} \mathrm{Nd}$ cannot be generated solely by the fractionation or accumulation of magmatic minerals. Hole 735B preserves widespread evidence of RPF which could induce kinetic isotope fractionation during crystal growth. However, the maximum kinetic isotope fractionations that can be generated in clinopyroxene are only ca. 0.02\%, therefore several cycles of dissolution and reprecipitation of isotopic signatures at grain boundaries are required to explain the range of $\delta^{146} \mathrm{Nd}$ observed in the gabbros. The large disconnect between the average 
composition of the oceanic crust $\left(\delta^{146} \mathrm{Nd}=-0.067 \%\right)$ and $\mathrm{MORB}$, combined with limited evidence of melt extraction to the upper crust at Hole 735B, led to the conclusion that melts involved in RPF have not contributed in a substantial way to the $\mathrm{Nd}$ isotope composition of erupted MORB.

Keywords: MORB, IODP, non-traditional stable isotopes, Hole 735B, reactive porous flow, kinetic isotope diffusion, Rayleigh fractionation

\section{INTRODUCTION}

The oceanic crust covers the majority of Earth's surface $(\sim 60 \%)$ and therefore accurate knowledge of its composition is imperative for constraining the composition of the silicate Earth and the long-term geochemical fluxes in recycling systems. Oceanic crust is produced along the global ocean ridge system which stretches over $60,000 \mathrm{~km}$ and produces $75 \%$ of Earth's volcanism (Crisp, 1984). The composition of mid-ocean ridge basalts (MORB), therefore can be used to provide important insights into the composition of Earth's most extensive crustal reservoir while also placing constraints on the composition of the upper mantle (e.g., Langmuir and Hanson, 1980; Hofmann, 1997; Workman and Hart, 2005; Gale et al., 2013). The magmas parental to these basalts were traditionally considered to have evolved by simple fractional crystallization, producing an oceanic crust consisting of $1-1.5 \mathrm{~km}$ of basalt and dolerite underlain by 4-5 km of gabbro (e.g., Dick et al., 1984; Klein, 2003). Although the chemical and isotope compositions of MORB are relatively homogenous compared to other magma types (e.g., ocean island basalts), MORB glasses can display significant elemental variations (White, 1985; Warren et al., 2009; Jenner and O'Neill, 2012). This compositional scatter is the result of the interplay between the contrasting effects of: (i) source composition (Rehkämper and Hofmann, 1997; Nielsen et al., 2018); (ii) differences in the extent of melting reflecting variations in mantle potential temperature (Klein and Langmuir, 1987; McKenzie and Bickle, 1988) or spreading rate (Regelous et al., 2016); and (iii) fractional crystallization processes which can be influenced by both the pressure of crystallization and magma composition (Michael and Cornell, 1998; Herzberg, 2004). However, a significant over-enrichment in the incompatible trace elements concentrations (e.g., Th, La) of magmas is observed compared to that which is predicted by simple fractional crystallization alone (White and Bryan, 1977; Hekinian and Walker, 1987; O'Neill and Jenner, 2012). Two distinct petrogenetic models have been advocated as the cause of these enrichments: (1) differentiation in an open system replenished-tapped-crystallizing (RTX) magma chambers (O'Hara, 1968; O’Neill and Jenner, 2012; Coogan and O'Hara, 2015) and (2) melt rock interaction resulting in the chromatographic separation of elements in the lower crust (Kamenetsky et al., 1998; Lissenberg and Dick, 2008; Lissenberg et al., 2013; Lissenberg and MacLeod, 2016). There is compelling geochemical and geophysical evidence that magma chambers at mid-ocean ridges operate as steady state open systems (Detrick et al., 1987; Johnson and Dick, 1992; Sinton and Detrick, 1992; White, 1993), supportive of an RTX model. Plutonic rocks from the oceanic crust are considered the crystallization products of
MORB differentiation (Coogan, 2014), however, whether MORB do in fact represent the erupted complement of the preserved oceanic gabbros remains debatable. At high temperature stable isotope fractionation can provide important insights in the nature and conditions of the processes involved in magma genesis (e.g., Dauphas et al., 2014; Millet et al., 2016; McCoy-West et al., 2018). This study presents high-precision double spike $\mathrm{Nd}$ stable isotope data for oceanic gabbros from Hole 735B and MORB from the Indian Ocean to test the various models of MORB genesis.

\section{MATERIALS AND METHODS}

Analyses were performed in the Arthur Holmes Geochemistry Labs at the Durham University. Basaltic glass, clinopyroxene or whole rock powders were weighed out to obtain $200 \mathrm{ng}$ of natural $\mathrm{Nd}$ and then spiked with a ${ }^{145} \mathrm{Nd}-{ }^{150} \mathrm{Nd}$ double spike (McCoy-West et al., 2017, 2020), and then dissolved using a conventional $\mathrm{HF}_{-} \mathrm{HNO}_{3}$ hotplate digestion. Neodymium was separated using well-established chromatographic techniques. Briefly, the rare earth elements (REE) were separated from the sample matrix using BioRad AG50W-x8 cation exchange resin. A second elongated column filled with Eichrom Ln$\mathrm{Spec}$ resin was then used to separate $\mathrm{Nd}$ from direct $\mathrm{Sm}$ isobaric interferences using dilute $\mathrm{HCl}$. For a more detailed description of the methodology refer to McCoy-West et al. (2017) and McCoy-West et al. (2020).

Neodymium isotope measurements were performed using a Thermo-Fisher Triton Plus thermal ionisation mass spectrometer (TIMS). Neodymium was measured as a metal ion in static collection mode using a double Re filament assembly. Each analysis usually comprised 400 cycles of data acquisition (8 s per integration). Stable $\mathrm{Nd}$ isotope ratios are expressed using conventional delta notation, where $\delta^{146} \mathrm{Nd}$ which is the per mil deviation in the measured ${ }^{146} \mathrm{Nd} /{ }^{144} \mathrm{Nd}$ relative to the widely measured reference standard JNdi-1:

$$
\delta^{146 / 144} N d=\left[\left(\frac{\frac{146 N d}{144 N d} \text { Sample }}{\frac{146 N d}{144 N d} \text { JNdi-1 }}\right)-1\right] \times 1000
$$

Double spike deconvolution was undertaken using the Wolfram Mathematica program and is based on the algebraic resolution method (Millet and Dauphas, 2014). As the radiogenic isotope ${ }^{143} \mathrm{Nd}$ is not used during double spike deconvolution, the spike proportion, and the geological and analytical fractionation factors resolved during deconvolution can be used to calculate the ${ }^{143} \mathrm{Nd} /{ }^{144} \mathrm{Nd}$ ratios of the samples (see McCoy-West et al., 2020, for equations). It has been demonstrated that these ${ }^{143} \mathrm{Nd} /{ }^{144} \mathrm{Nd}$ 
values agree within analytical uncertainty of previously published values for conventionally processed samples (see Figure 1 in McCoy-West et al., 2017) providing confidence of the accuracy of the $\delta^{146} \mathrm{Nd}$ obtained from the same measurement. As a secondary check of data quality, it is also now possible to independently deconvolve the $\delta^{148 / 144} \mathrm{Nd}$ of the samples to confirm the mass dependence of analyses (Figure 1). The data presented here have been normalized to JNdi-1 $=0$, to correct for small offsets in the measured composition of JNdi-1 during different analytical periods due to differences in faraday collector efficiency (McCoy-West et al., 2020). Propagated uncertainties were calculated using the $95 \%$ standard error on the average of JNdi-1 for the correction period. Applying a secondary normalization such as this is common practice for radiogenic TIMS data (e.g., Bennett et al., 2007; McCoy-West et al., 2013) and stable isotope data generated by MC-ICP-MS (e.g., Goldberg et al., 2013; Millet and Dauphas, 2014; Neely et al., 2018; McCoy-West et al., 2019) in order to deal with small amounts of non-exponential mass bias that is not accounted for by internal corrections methods. The long-term reproducibility of the $\delta^{146} \mathrm{Nd}$ measurements is considered to better than $\pm 0.015 \%$ (McCoy-West et al., 2017, 2020).

\section{SAMPLES AND RESULTS}

\section{Samples}

This study focuses on samples from Ocean Drilling Program Hole 735B in the Atlantis II Transform Fault area located at $32^{\circ} \mathrm{S}$ $57^{\circ} \mathrm{E}$ on the Southwest Indian Ridge (SWIR) to the southeast of Madagascar (Figure 2). This region contains $12 \mathrm{Ma}$ gabbroic ocean crust (John et al., 2004; Baines et al., 2009) that is exposed

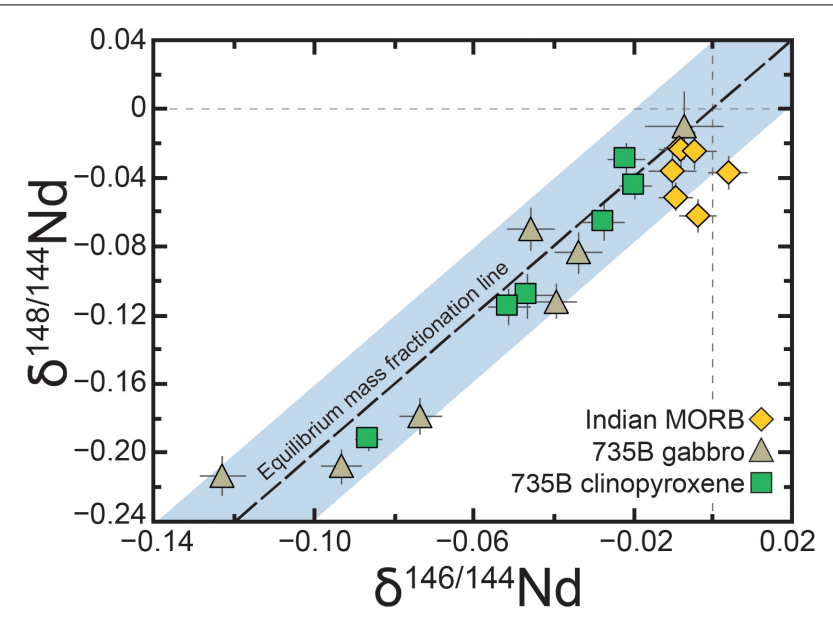

FIGURE 1 | Plot showing the mass dependent covariation between $\delta^{146} \mathrm{Nd}$ and $\delta^{148} \mathrm{Nd}$ for samples measured in this study. Shaded field represents an uncertainty in $\delta^{148} \mathrm{Nd}$ of $\pm 0.038 \%$, which is based on the long-term uncertainty in $\delta^{146} \mathrm{Nd}( \pm 0.015 \%$; McCoy-West et al., 2020) but has been increased proportionally based on the relative mass difference between the isotopes and the less precise counting statistics due to the smaller ion beam on ${ }^{148} \mathrm{Nd}$.

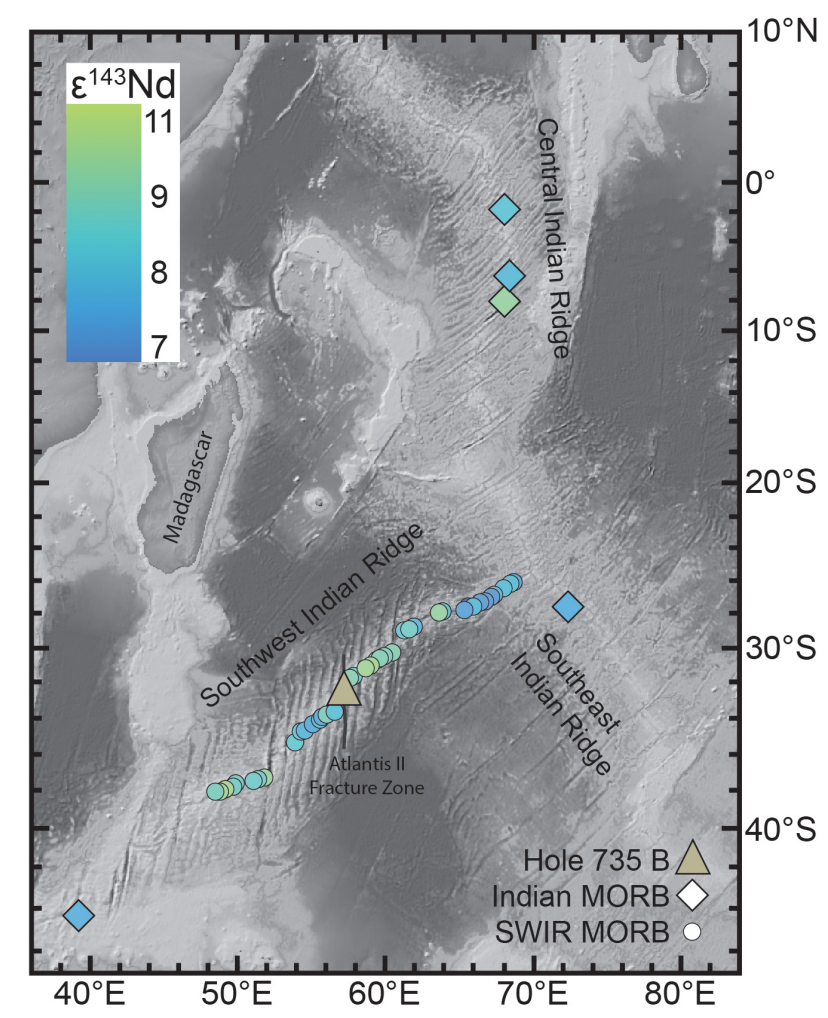

FIGURE 2 | Map showing the major spreading ridges in the Indian Ocean and the locations of Hole 735B and the MORB glasses analyzed in this study. Symbols for MORB have been color coded based on their radiogenic $\mathrm{Nd}$ isotope compositions (diamonds samples herein; circles previously published data for the Southwest Indian Ridge (Meyzen et al., 2005). Bathymetry is from Ryan et al. (2009).

on a $5-\mathrm{km}$ transverse ridge (Atlantis Bank) which formed as the result of detachment faulting from 13 to $10 \mathrm{Ma}$ (Dick et al., 1991). The spreading rate in this region is $\sim 1.6 \mathrm{~cm} /$ year which is extremely slow (Baines et al., 2007). Hole 735B is located $\sim 95 \mathrm{~km}$ south of the present-day ridge axis and drilled $1508 \mathrm{~m}$ into the gabbroic rocks unroofed at the Atlantis Bank core complex, recovering a plutonic section dominated by series of generally coarse-grained olivine gabbros cross-cut by more evolved rocks (gabbronorites, oxide gabbros) and subordinate troctolite (Dick et al., 1991; Coogan et al., 2001; Natland and Dick, 2001). More felsic leucocratic igneous rocks are rare, making up $\leq 1 \%$ of the Hole 735B core and are generally present as highly altered, small crosscutting veins (Dick et al., 2000). Petrologic evidence and fluid inclusion studies suggest the ocean crust at Hole $735 \mathrm{~B}$ is $4 \pm 1 \mathrm{~km}$ thick, with $60-70 \%$ of the total gabbro column sampled (Vanko and Stakes, 1991; Muller et al., 1997).

To supplement the gabbroic rocks analyses of MORB glass from the Indian Ocean where undertaken. These samples are widely distributed coming from all the major ridge segments in the Indian Ocean (SWIR, Southeast Indian Ridge and Central Indian Ridge; Figure 2) and have been previously been analyzed for Sr-Nd-Hf-Pb and Os radiogenic isotopes (Salters, 1996; Schiano et al., 1997; Escrig et al., 2004). 


\section{Results}

\section{Indian Ocean MORB}

Measurements of six MORB glasses from the Indian Ocean show a restricted range in $\mathrm{Nd}$ stable isotopes with $\delta^{146} \mathrm{Nd}$ ranging from -0.015 to $-0.029 \%\left(\delta^{146} \mathrm{Nd}=14 \mathrm{ppm}\right.$; Figure 3 and Table 1). The average composition of the Indian Ocean MORB is $\delta^{146} \mathrm{Nd}=-0.025 \pm 0.010 \%(n=7 ; 95 \% \mathrm{SE}= \pm 0.005 \% 0)$ and identical within uncertainty to that of MORB from the Garrett Fracture Zone (Pacific Ocean) reported previously with $\delta^{146} \mathrm{Nd}=-0.022 \pm 0.019 \%(n=4 ; 95 \% \mathrm{SE}= \pm 0.025 \%$; McCoy-West et al., 2017). Radiogenic neodymium isotope composition of MORB vary from $\varepsilon^{143} \mathrm{Nd}=+7.8$ to +9.8 , consistent with previous analyses from this region (Hamelin et al., 1986; Meyzen et al., 2005) and show no covariation with $\delta^{146} \mathrm{Nd}$ (Figure 4). Average global MORB is calculated as $\delta^{146} \mathrm{Nd}=-0.024 \pm 0.013 \%$ ( $\left.n=11 ; 95 \% \mathrm{SE}= \pm 0.004 \% 0\right)$ and is similar to the composition of terrestrial magmatic rocks and within the uncertainty of the composition of chondritic meteorites (Figure 3).

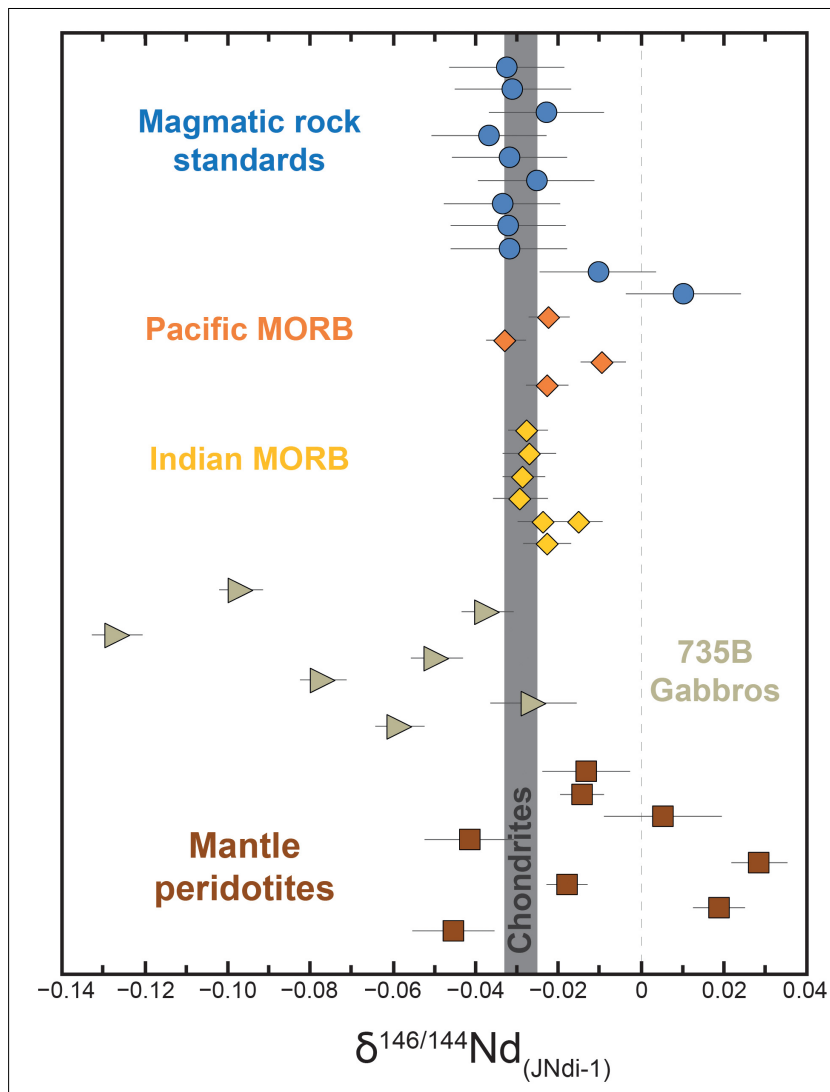

FIGURE 3 | Comparison of $\delta^{146} \mathrm{Nd}$ in a range of terrestrial rocks. Indian MORB and Hole 735B gabbros are new measurements, all other data is from McCoy-West et al. (2017). Most data points are plotted with propagated two standard errors, except the magmatic rock standards which are plotted with the long-term reproducibility $( \pm 0.015 \%)$ due to averaging multiply measurements/digestions. The gray band represents the chondritic average $\pm 95 \%$ standard error on the mean $(-0.029 \pm 0.004 \% ; n=38$; McCoy-West et al., 2017).

\section{B Gabbro Whole Rock}

The gabbro's from Hole $735 \mathrm{~B}$ possess highly variable $\delta^{146} \mathrm{Nd}$ with values ranging from -0.026 to $-0.126 \%$ ( $n=7$; $\delta^{146} \mathrm{Nd}=100 \mathrm{ppm}$; Figure 3 and Table 2), which extend to the lightest $\mathrm{Nd}$ stable isotope compositions so far observed. This large variation in $\delta^{146} \mathrm{Nd}$ is not correlated with the $\mathrm{Nd}$ concentration (1.4-4.2 ppm) or $\varepsilon^{143} \mathrm{Nd}$ (ca. +9.5; excluding MS20-10 $\left.\varepsilon^{143} \mathrm{Nd}=+6.8\right)$ with the samples possessing relatively similar radiogenic isotope compositions (Figure 4). Whole rock geochemistry is correlated with $\delta^{146} \mathrm{Nd}$ (Figure 5): strong $\left(r^{2}>0.6\right)$ positive correlations are observed with $\mathrm{SiO}_{2}$, $\mathrm{Al}_{2} \mathrm{O}_{3}, \mathrm{Na}_{2} \mathrm{O}$, and $\mathrm{CaO}$; with negative correlations observed against $\mathrm{MgO}, \mathrm{FeO}_{\mathrm{T}}$, and $\mathrm{MnO}$. However, occasionally some samples appear as outliers, specifically sample $\mathrm{BN}-1(\mathrm{~F})$ has a very light $\delta^{146} \mathrm{Nd}$ of $-0.126 \%$ which is distinct from the strong trend formed by the rest of the gabbros (Figure 5C). Despite these strong correlations between $\delta^{146} \mathrm{Nd}$ and major element contents, no correlation is observed with indicators of magmatic differentiation (e.g., Mg\#; Figure 6A), with the gabbros possessing an extremely narrow range of $\mathrm{Mg} \#$ from 0.73 to 0.79 .

\section{B Gabbro Clinopyroxene}

Clinopyroxene separates from Hole $735 \mathrm{~B}$ possess between 2.8 and $13.3 \mathrm{ppm} \mathrm{Nd}$ (Figure 4A), excluding one separate from MS 41-18 that has a usually high $\mathrm{Nd}$ concentration of $80.9 \mathrm{ppm}$ (Table 2). Comparable to the whole rocks the clinopyroxene separates also possess extremely variable $\delta^{146} \mathrm{Nd}$ with values ranging from -0.016 to $-0.090 \%$ ( $n=7$; $\delta^{146} \mathrm{Nd}=84 \mathrm{ppm}$; Table 2) with a constant radiogenic isotope composition $\left(\varepsilon^{143} \mathrm{Nd}=+9.0\right.$ to +9.6 ; Figure $\left.4 \mathbf{B}\right)$. For the one gabbro MS20-10, where both the whole rock and clinopyroxene composition are available the clinopyroxene is resolvably heavier $\left(\Delta^{146} \mathrm{Nd}_{\text {clinopyroxene-wholerock }}=+0.047 \%\right)$. Qualitatively this finding holds when comparing the other samples using their whole rock $\mathrm{Al}_{2} \mathrm{O}_{3}$ and $\mathrm{Na}_{2} \mathrm{O}$ contents with the majority of clinopyroxene separates forming a secondary trend at heavier $\delta^{146} \mathrm{Nd}$ than the whole rock samples at similar major element compositions (Figures 5C,D).

\section{DISCUSSION}

\section{Spatial Variations in the Nd Isotope Composition of the Oceanic Crust Radiogenic Nd Isotope Variability}

One of the fundamental strengths of radiogenic isotopes is they remain unfractionated by magmatic process (e.g., fractional crystallization; partial melting), but rather provide a timeintegrated tracer of parent-daughter fractionation (e.g., Sm from $\mathrm{Nd}$ ). The heterogenous isotopic compositions of MORB globally has been used to map distinct mantle domains and trace long-term recycling of isotopically enriched components in the depleted MORB mantle (Zindler and Hart, 1986; Salters and Stracke, 2004; Hofmann, 2007). Indian MORB has less radiogenic $\mathrm{Nd}$ and more radiogenic $\mathrm{Sr}$ at the same $\mathrm{Pb}$ isotope composition than Atlantic, and Pacific MORB (see Figure 2 in Stracke et al., 2005). Despite this distinction significant variations in $\varepsilon^{143} \mathrm{Nd}$ 
TABLE 1 | Neodymium concentrations and isotopic compositions of glass from Indian mid-ocean ridge basalts.

\begin{tabular}{|c|c|c|c|c|c|c|c|c|c|}
\hline Sample & Location & Nd (ppm) & ${ }^{143} \mathrm{Nd} /{ }^{144} \mathrm{Nd}$ & $\varepsilon \mathbf{N d}$ & $\delta^{146 / 144} \mathrm{Nd}$ & $\delta^{148 / 144} \mathrm{Nd}$ & $\delta^{146 / 144} \mathrm{Nd}_{\text {NORM }}$ & $2 S D$ & $n$ \\
\hline MD34 D6 & SWIR & 15.28 & $0.513043 \pm 2$ & 7.89 & $-0.008 \pm 0.004$ & $-0.023 \pm 0.007$ & $-0.027 \pm 0.005$ & & \\
\hline MD37 03-01 D1-26 & SEIR & 7.98 & $0.513038 \pm 3$ & 7.81 & $-0.004 \pm 0.005$ & $-0.062 \pm 0.010$ & $-0.023 \pm 0.006$ & & \\
\hline MD57 D9-1 & $\mathrm{CIR}$ & 3.77 & $0.513140 \pm 3$ & 9.80 & $-0.008 \pm 0.006$ & $-0.024 \pm 0.011$ & $-0.027 \pm 0.006$ & & \\
\hline MD57 D9-6 & $\mathrm{CIR}$ & 4.64 & $0.513147 \pm 3$ & 9.93 & $-0.009 \pm 0.004$ & $-0.051 \pm 0.008$ & $-0.028 \pm 0.005$ & & \\
\hline MD57 D'10-1 & $\mathrm{CIR}$ & 12.58 & $0.513058 \pm 3$ & 8.20 & $-0.010 \pm 0.006$ & $-0.036 \pm 0.012$ & $-0.029 \pm 0.007$ & & \\
\hline MD57 D13-7 & $\mathrm{CIR}$ & 12.18 & $0.513070 \pm 3$ & 8.42 & $-0.004 \pm 0.005$ & $-0.024 \pm 0.011$ & $-0.023 \pm 0.006$ & & \\
\hline \multirow[t]{3}{*}{ MD57 D13-7\# } & & 12.18 & $0.513075 \pm 3$ & 8.53 & $0.004 \pm 0.005$ & $-0.037 \pm 0.010$ & $-0.015 \pm 0.006$ & & \\
\hline & & & & & Average-Indian: & & $-0.025 \pm 0.005$ & \pm 0.010 & 7 \\
\hline & & & & Glo & I MORB average: & & $-0.024 \pm 0.004$ & \pm 0.013 & 11 \\
\hline
\end{tabular}

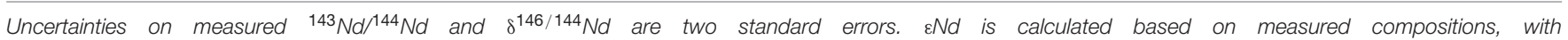

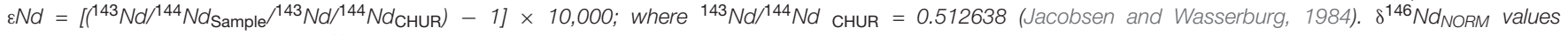

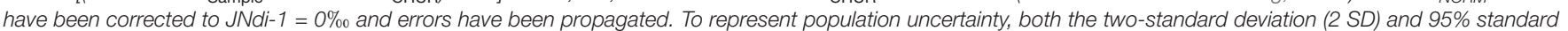

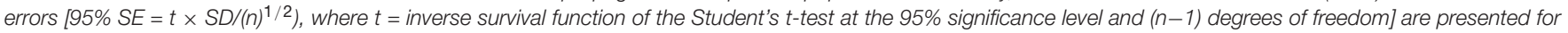

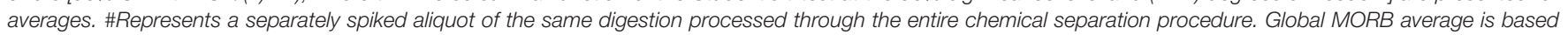
on this data herein and presented in McCoy-West et al. (2017).

are observed across the Indian Ocean between spreading ridges (Hamelin et al., 1986; Robinson et al., 2001; Coogan et al., 2004; Meyzen et al., 2005), and even within individual segments of the SWIR (Figure 2). The previous characterization of Hole 735B (Kempton et al., 1991; Hart et al., 1999; Holm, 2002) means it provides an ideal test case to examine this isotopic heterogeneity with depth (Figure 7). Previous analyses of gabbro from Hole $735 \mathrm{~B}$ have $\varepsilon^{143} \mathrm{Nd}$ values spanning a significant range from +7.7 to +10.6 , which is nearly the entire range observed in Indian MORB. The average composition of Hole $735 \mathrm{~B}$ drill core is calculated as $+9.29 \pm 0.14$ (95\% SE) and is within uncertainty of basalts collected adjacent to the overlying Atlantis II fracture zone $\left(\varepsilon^{143} \mathrm{Nd}=+9.13 \pm 0.19\right)$, suggesting that the major sources of gabbroic rocks and overlying MORB are broadly similar. The clinopyroxene and whole rock samples analyzed herein are generally indistinguishable from the Hole 735B average, except sample MS20-10 $\left(\varepsilon^{143} \mathrm{Nd}=+6.8\right)$ which is the least radiogenic so far measured but remains well within the range of heterogeneity observed along the SWIR (Figure 7). The preservation of extreme isotopic heterogeneity in oceanic mantle between constituent phases and across small length is increasingly being recognized as a common phenomenon (Burton et al., 2012; Lambart et al., 2019). This is not an unexpected results given the depleted mantle represents a mixture of materials at different stages in their evolution, and is therefore unlikely to be a isotopically homogeneous (e.g., Salters and Stracke, 2004).

\section{Stable Nd Variations in Hole 735B}

Stable isotope ratios are time-independent and solely fractionated by the processes operating. At equilibrium, the magnitude of isotopic fractionation is proportional to the relative mass difference between the isotopes and inversely proportional to temperature $\left(1 / T^{2}\right)$ (Bigeleisen and Mayer, 1947; Urey, 1947). Due to the well characterized nature of Hole 735B it provides a unique opportunity to study stable isotope fractionations in the lower oceanic crust. The oceanic gabbros have $\delta^{146} \mathrm{Nd}$ values extending to extremely light compositions $(-0.026$ to $-0.127 \%$; Figure 3$)$. In Hole $753 \mathrm{~B}$ at long wavelengths $(>200 \mathrm{~m})$ there is generally a good covariation between the chemical compositions of the major silicate phases, consistent with the in situ crystallization of four distinct olivine gabbro bodies (Dick et al., 2002). Three major mineralogical discontinuities have been identified in the lower portion of Hole 735B (picked on the basis of plagioclase anorthite content: see Figure 16 in Dick et al., 2002). These bodies are also clearly delineated by whole rock major element compositions, with the gabbroic rocks in each body generally become slightly more evolved up section (lower Mg\#; Figure 8A). Two of the lightest gabbro samples in Hole 735B occur above 650 mbsf (Figure 8B), however, when also considering the composition of the clinopyroxene separates no clear relationship between $\delta^{146} \mathrm{Nd}$ and depth is observed. Unfortunately, the current dataset remains too limited to constrain the variability of $\delta^{146} \mathrm{Nd}$ with depth, either throughout the entire drill core or relative to the individual position of the samples within the discrete gabbro bodies (Figure 8B).

\section{Resolving the Causes of Nd Stable Isotope Variation in Hole 735B}

The lower oceanic crust is an extremely complex magmatic environment. Indeed, the crustal section at Hole 735B preserves 952 discrete intervals on basis of clear textural and mineralogic differences (Dick et al., 2002). The complexity of slow spreading ridges means that a range different process maybe contributing to the natural variations observed in $\delta^{146} \mathrm{Nd}$. Ultimately, the whole rock compositions of the preserved gabbros integrate the effects of differences in mineral proportions, mineral compositions and any secondary modification through alteration.

\section{Possible Low Temperature Fractionation?}

Significant fractionation of both boron and iron isotopes have been shown to be caused by alteration in the oceanic crust (Spivack and Edmond, 1987; Rouxel et al., 2003). Boron is highly enriched in seawater and fluids and $\mathrm{Fe}$ is a major element in most mineral phases which is also sensitive to redox changes. In contrast, $\mathrm{Nd}$ a light (L)REE is generally moderately to highly incompatible in most silicate phases, possess a single valence 

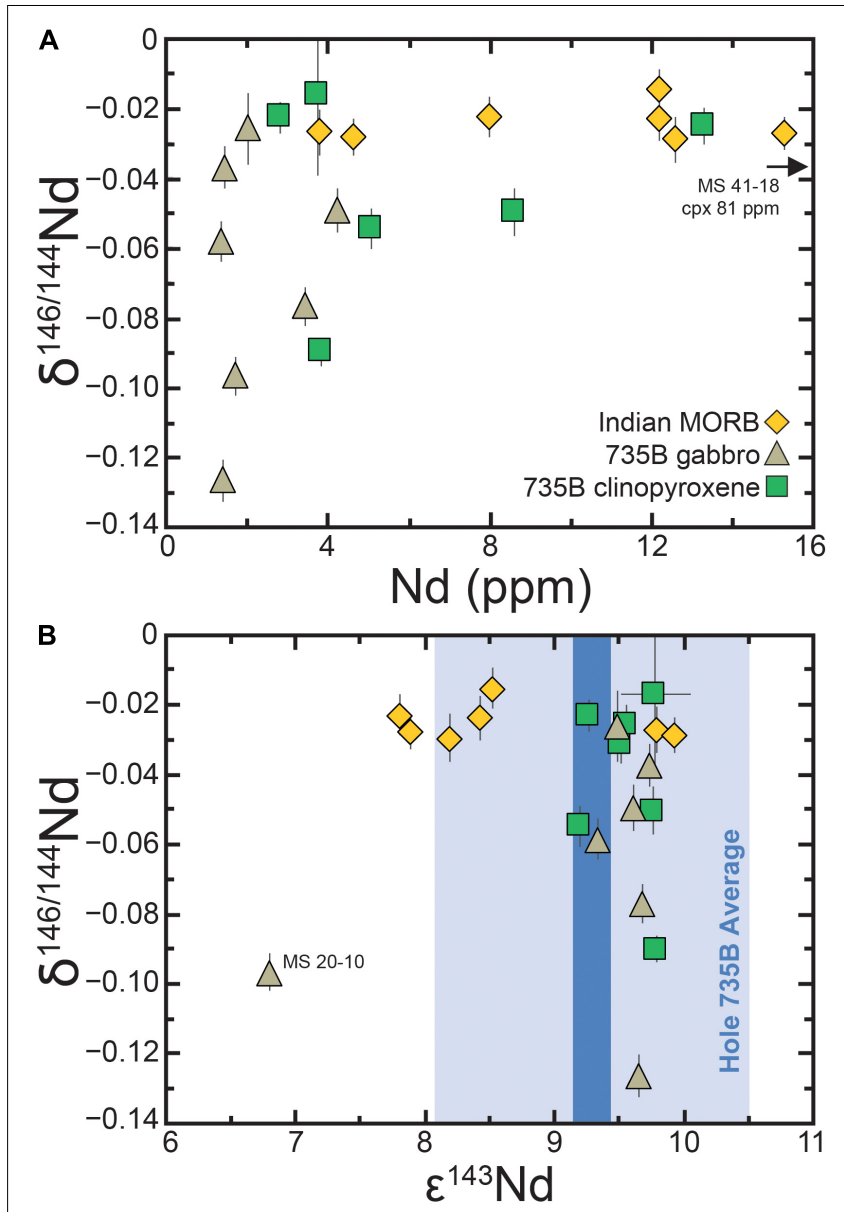

FIGURE 4 | Comparison of the $\mathrm{Nd}$ contents and isotopic compositions of Indian MORB and Hole 735B gabbro whole rocks and clinopyroxene separates. Graphs of $\delta^{146} \mathrm{Nd}$ versus $\mathrm{Nd}$ concentration (A) and $\varepsilon^{143} \mathrm{Nd}$ (B), respectively. Uncertainties on $\delta^{146} \mathrm{Nd}$ are propagated two standard errors. The blue shaded area represents the average $\mathrm{Nd}$ isotope composition of the Hole 735B (Kempton et al., 1991; Hart et al., 1999; Holm, 2002; herein). The light blue represents the average \pm 2 standard deviations: $\left(\varepsilon^{143} \mathrm{Nd}=9.29 \pm 1.21\right.$; ${ }^{143} \mathrm{Nd} /{ }^{144} \mathrm{Nd}=0.513114 \pm 62 ; n=72$ ) with the dark blue band representing the $95 \%$ standard error of the mean $\left(\varepsilon^{143} \mathrm{Nd}= \pm 0.14 ;{ }^{143} \mathrm{Nd} /{ }^{144} \mathrm{Nd}= \pm 8\right)$.

state (3+), and is extremely fluid immobile (Bau, 1991). These characteristics make $\mathrm{Nd}$ generally very robust to secondary modification. Oxygen isotope evidence shows that abundant seawater penetration appears to be limited to the upper part of the crust preserved at Hole 735B ( $\geq 500$ mbsf; Kempton et al., 1991; Hart et al., 1999; Gao et al., 2006). Given that the samples analyzed here are below this depth and the extremely low concentration of $\mathrm{Nd}$ in seawater (ca. 3-4 ppt), it is reasonable to conclude that seawater interaction had no effect on the $\delta^{146} \mathrm{Nd}$ values measured here. Bach et al. (2001) undertook a detailed study of the effects of alteration in Hole $735 \mathrm{~B}$ with an overall decrease in the intensity of hydrothermal alteration observed with increasing depth. Alteration becomes rarer below $600 \mathrm{mbsf}$ with the lowermost part of the section (500-1500 mbsf) showing the effects of a complex low-temperature (ca. $250^{\circ} \mathrm{C}$ ) alteration history probably related to the tectonic uplift of the basement.
This low-temperature alteration is localized to fractured regions where intense alteration of the host rocks can be observed adjacent to secondary mineral (smectite, chlorite, calcite, zeolite, sulfide, and Fe-oxyhydroxides) filled veins (Bach et al., 2001). Bienvenu et al. (1990) showed that during intense alteration of basalt the REE can become mobilized during the breakdown of secondary minerals. Here, we have focused on the freshest possible samples to eliminate alteration as a factor in interpreting geochemical signals. The majority of the gabbros possess a restricted range of $\mathrm{Nd}$ concentration (1.3-2.0 ppm; Table 2) but span the entire range $\delta^{146} \mathrm{Nd}$ (Figure 4A), with no correlation observed that could be attributed to $\mathrm{Nd}$ loss. Neodymium stable isotope compositions have also been compared to other common indicators of alteration intensity such as loss on ignition (Figure 9A) or enrichment of fluid mobile elements (e.g., Rb; Figure 9B) and remain uncorrelated with these parameters. Further evidence of the inability of alteration to fractionate $\delta^{146} \mathrm{Nd}$ comes from analyses of chondritic meteorites, which contain a range of exotic phases including REE enriched sulfides that are highly susceptible to alteration, that had experienced variable terrestrial alteration but showed no systematic change in $\delta^{146} \mathrm{Nd}$ values with increasing weathering intensity (see Figure 6 in McCoy-West et al., 2017). Therefore, we are confident the variations in $\delta^{146} \mathrm{Nd}$ observed here are generated by magmatic processes during formation of the oceanic crust.

\section{Fractionation or Accumulation of Magmatic Crystals}

The gabbros at Hole 735B are dominated by three major phases: (1) plagioclase is present in every rock type examined, is the most abundant phase (50-65\% in representative gabbros; Dick et al., 1999), and typically occurs in near cotectic proportions with clinopyroxene and olivine (Bloomer et al., 1991); (2) clinopyroxene is next most prevalent phase, with the majority of gabbros containing from 15 to $45 \%$ (Dick et al., 1999), its abundance varies inversely with the amount of plagioclase (Dick et al., 2002; Niu et al., 2002); and (3) olivine is a subordinate component and generally only constitutes 5-10\% of the olivine gabbros (Dick et al., 1999). Clinopyroxene is the major host of $\mathrm{Nd}$ in the gabbroic rocks of Hole 735B. Due to distortions of the crystal lattice partition coefficients are dependent on the temperature, pressure and composition of a mineral during crystallization (Wood and Blundy, 1997). Clinopyroxene is characterized by three crystallographically unique polyhedra, with the LREE mainly occupying the eightfold coordinated M2 site (Ross et al., 2013; Bédard, 2014). Higher $\mathrm{Al}_{2} \mathrm{O}_{3}\left({ }^{I V} \mathrm{Al}\right)$ contents significantly increase the compatibility of REE in clinopyroxene, due to the high $\mathrm{Al}_{2} \mathrm{O}_{3}$ contents ( ${ }^{I V} \mathrm{Al}$ up to 0.4 ) in typical Hole735B gabbros $\mathrm{D}_{\mathrm{Nd}}$ values of $0.4-0.6$ are likely (Hill et al., 2000). Due to the high modal abundance of plagioclase it could also host a significant amount of $\mathrm{Nd}$. Plagioclase is a framework of linked ( $\mathrm{Si}-\mathrm{Al}$ )-O tetrahedra, with large interstices filled with $\mathrm{Ca}$ and $\mathrm{Na}$ ions. The $\mathrm{REE}$ occur in sixfold coordination in plagioclase (Cherniak, 2003), were they can replace $\mathrm{Na}$ following a coupled substitution due to their similar atomic radii $(\mathrm{Nd}=0.983 \AA ; \mathrm{Na}=1.02 \AA$; Shannon, 1976). The partitioning of $\mathrm{Nd}$ into plagioclase is dependent on the anorthite content 


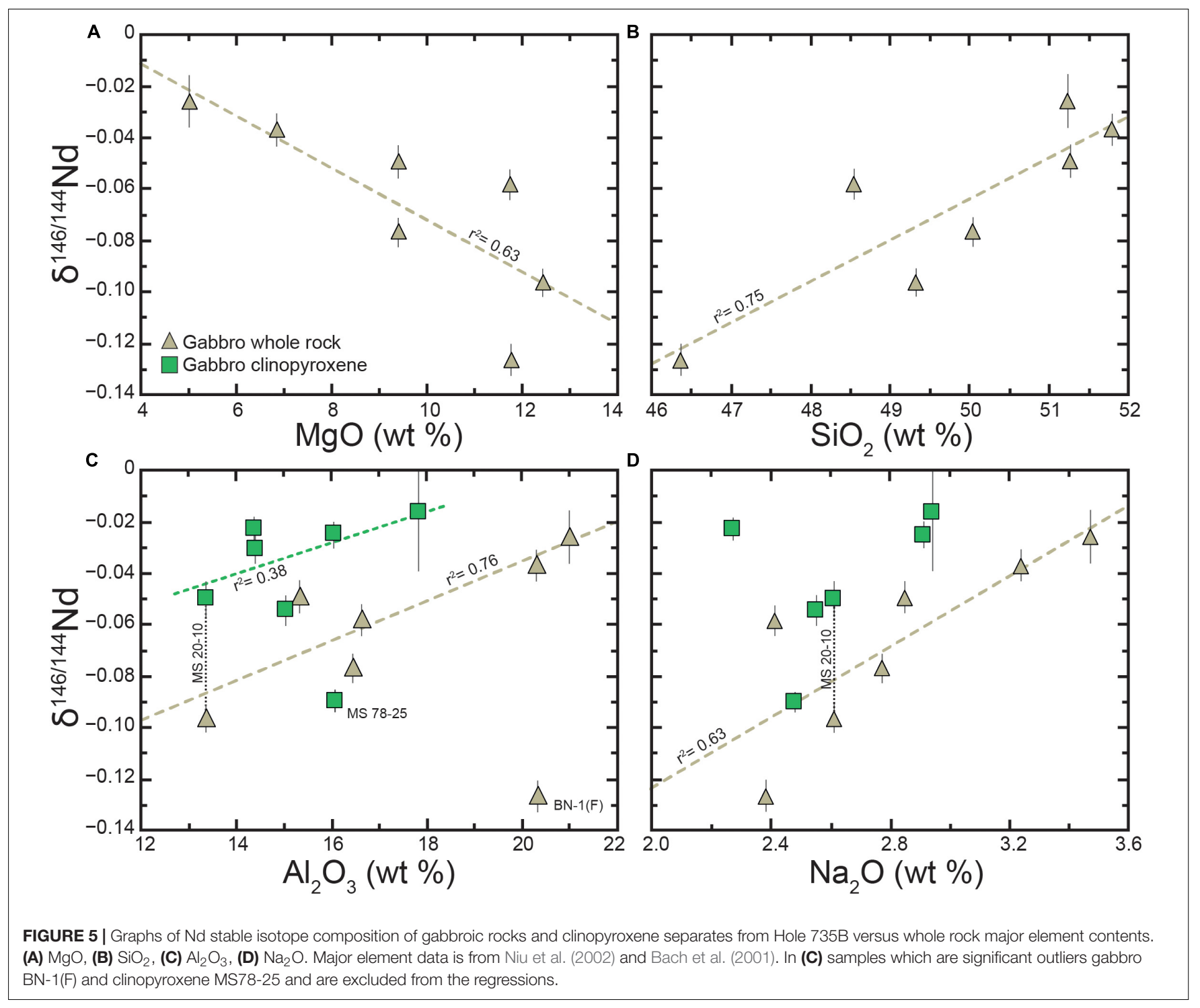

$\left(\mathrm{An}=\mathrm{Ca} /[\mathrm{Ca}+\mathrm{Na}] ; \max \mathrm{An}_{60}\right.$ in $\left.735 \mathrm{~B}\right)$ with $\mathrm{D}_{\mathrm{Nd}}$ values of 0.1-0.15 probable (Bindeman and Davis, 2000; Tepley et al., 2010; Sun et al., 2017). The REE are very incompatible in olivine $\left(D_{\mathrm{Nd}}=0.0002\right.$; Prinzhofer and Allégre, 1985) and therefore olivine is not considered a likely host of $\mathrm{Nd}$ and will not be discussed further.

Geochemical evidence shows that the gabbroic rocks preserved at Hole $735 \mathrm{~B}$ are not simple quenched melts and instead they represent crystal cumulates. Their whole rock compositions have $\mathrm{Mg} \#$ that are too high, $\mathrm{TiO}_{2}$ contents that are too low and too wide a range in $\mathrm{CaO} / \mathrm{Al}_{2} \mathrm{O}_{3}$ to be in equilibrium with melts (Niu et al., 2002). Gabbro whole rock compositions (e.g., $\mathrm{CaO}, \mathrm{Sc}$ ) are instead largely a function of the relative modal proportions of clinopyroxene and plagioclase (see Figure 6 in Niu et al., 2002). Niu et al. (2002) demonstrated that it is possible to calculate the proportion of clinopyroxene using the $\mathrm{CaO} / \mathrm{Al}_{2} \mathrm{O}_{3}\left(\mathrm{R}_{\mathrm{C} / \mathrm{A}} ; \mathrm{Cpx} \#=\left[1.3835 \times \mathrm{R}_{\mathrm{C} / \mathrm{A}}-\right.\right.$ $\left.0.5163] /\left[1.2571 \times \mathrm{R}_{\mathrm{C} / \mathrm{A}}+0.4587\right]\right)$ as it is insensitive to dilution by more mafic components (i.e., olivine). A strong correlation is observed between $\delta^{146} \mathrm{Nd}$ in Hole $735 \mathrm{~B}$ gabbros and the proportion of clinopyroxene (Figure 6B), with increasing amounts of clinopyroxene correlated with lighter isotopic compositions. Stable isotope compositions are process dependent and therefore the accumulation or fractionation of a significant amount of crystal cargo with a unique isotopic composition can cause resolvable changes in the isotopic composition of a cogenetic rock suite (e.g., Sossi et al., 2012; Millet et al., 2016; McCoy-West et al., 2018). Stable isotope theory suggests that at equilibrium with a fixed valance state heavy isotopes will prefer the site with the stiffest bonds (i.e., lower coordination number; Schauble, 2004). The coordination of the REE in silicate glass is highly composition dependent with sixfold to ninefold coordination observed (e.g., Ponader and Brown, 1989). Existing experimental work suggests that $\mathrm{Nd}$ (and the LREE) are predominantly sevenfold coordinated in silicate and other oxide glasses, although sixfold coordination 

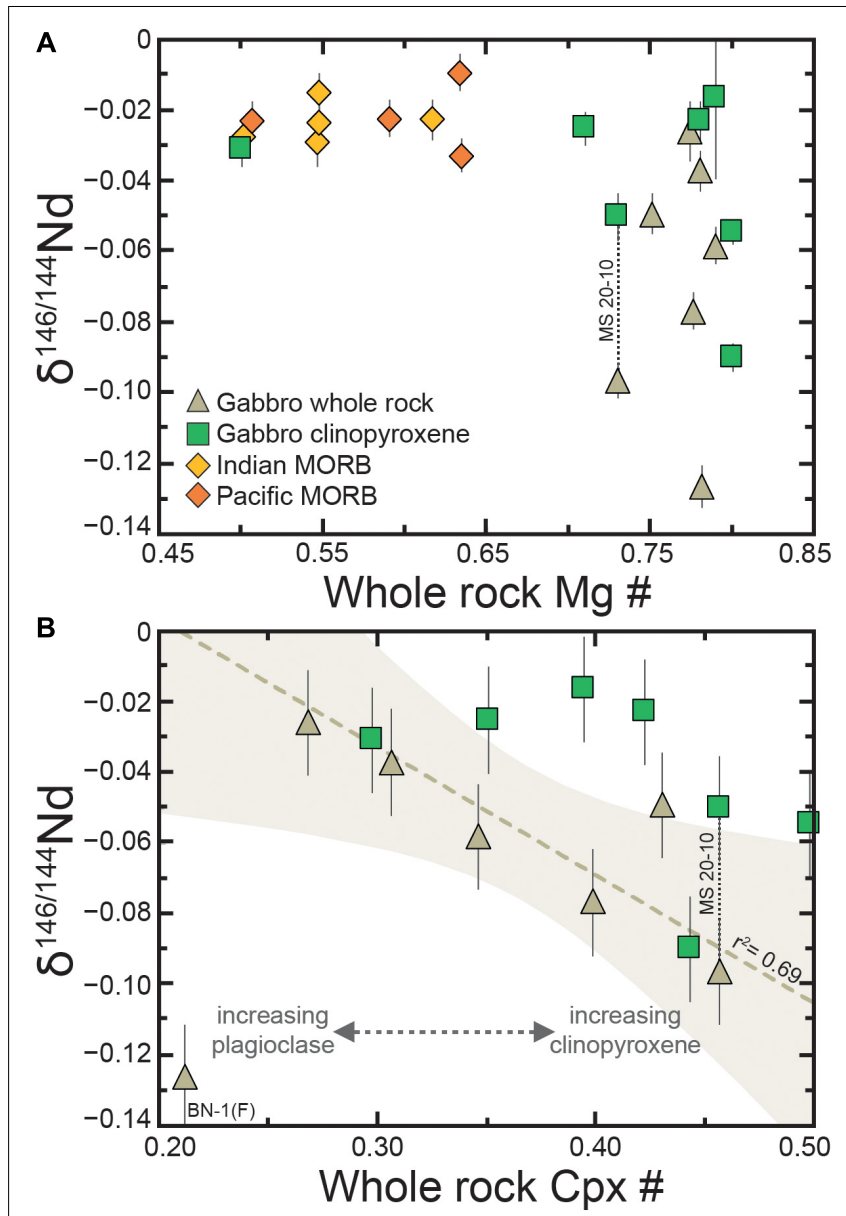

FIGURE 6 | Graphs of $\delta^{146} \mathrm{Nd}$ against whole rock Mg\# (A) and whole rock cpX\# (B), respectively. (A) Note the distinctly different compositions of MORB and Hole 735B gabbros ( $\mathrm{Mg} \#=$ molar $\mathrm{Mg} /\left[\mathrm{Mg}+\mathrm{Fe}^{2+}\right]$ ).

(B) Clinopyroxene-number (cpx\# $=\mathrm{cpx} /[\mathrm{cpx}+$ plag]) estimates the relative mass proportions of clinopyroxene and plagioclase in a sample based on the $\mathrm{CaO} / \mathrm{Al}_{2} \mathrm{O}_{3}$ ratio and is calculated using the formula in Niu et al. (2002). A strong negative correlation is observed between $\delta^{146} \mathrm{Nd}$ and cpX\#.

Regression line and uncertainty envelope (shaded area) is calculated through the data excluding sample BN-1(F) using Isoplot (Ludwig, 2008) assuming a $2.5 \%$ uncertainty on the cpx\# and the long-term uncertainty on $\delta^{146} \mathrm{Nd}$ $( \pm 0.015)$. The clinopyroxene separates are variably offset, generally to heavier values, relative to the whole rock relationship consistent with the operation of a disequilibrium process.

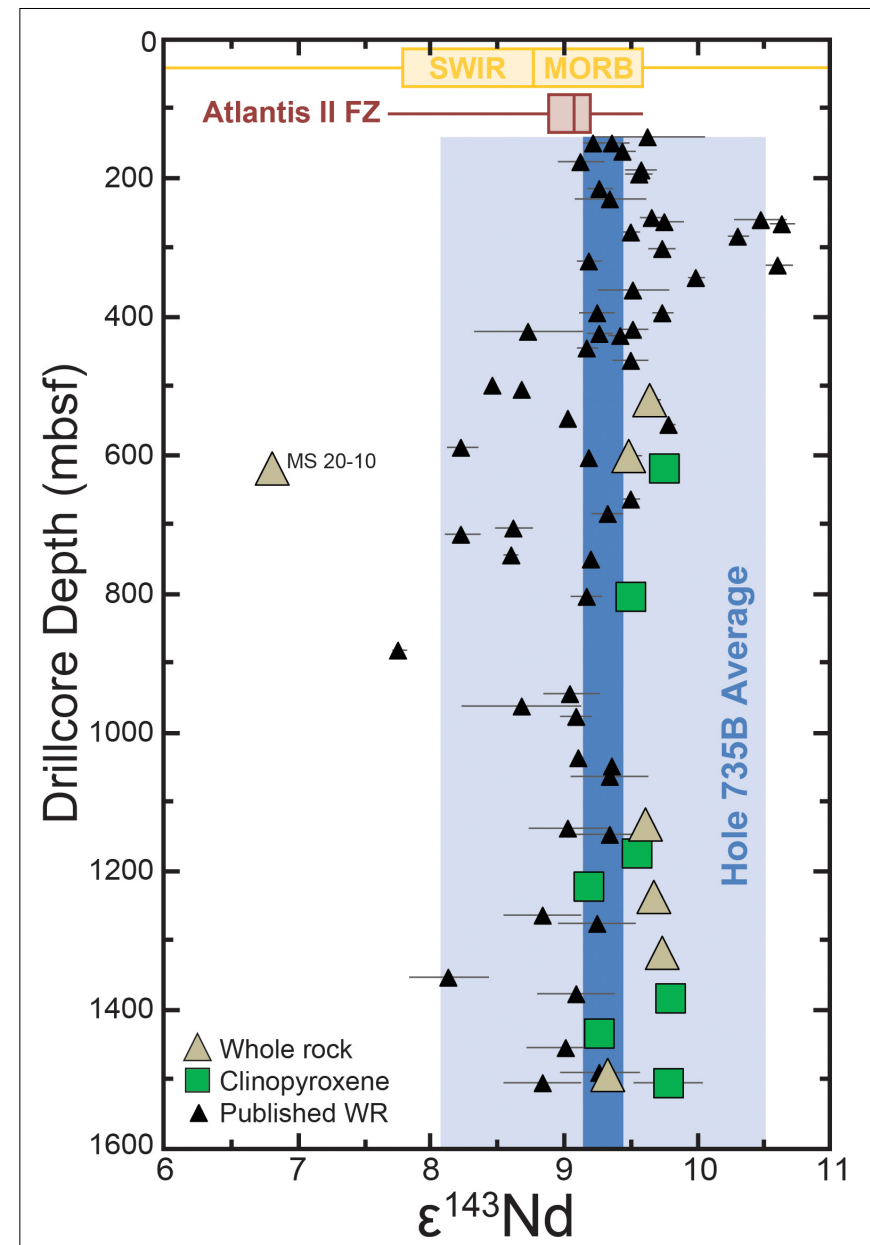

FIGURE 7 | Downhole variation in radiogenic $\mathrm{Nd}$ isotopes $\left(\varepsilon^{143} \mathrm{Nd}\right)$ in Hole 735B. Previously published compositions for 735B gabbros (Kempton et al., 1991; Hart et al., 1999; Holm, 2002) are not shown above 100 m. Box and whisker plots are shown for basalts immediately adjacent to the Atlantis II fracture zone (Robinson et al., 2001; Coogan et al., 2004) and Southwest Indian Ridge MORB (Robinson et al., 2001; Coogan et al., 2004; Meyzen et al., 2005). The blue shaded field is the average composition of Hole 735B as shown in Figure 4.

To explain the trend seen in Figure $6 \mathbf{B}$ would require that the gabbros with highest clinopyroxene contents represent magmas that have previously fractionated a significant amount of isotopically heavy clinopyroxene and then migrated and crystallized with a significantly lighter whole rock composition. To explore this process, we undertook Rayleigh fractionation modeling to show the effect of crystallizing isotopically heavy clinopyroxene (Figure 10): based on the measured offset in sample MS 20-10 $\left(\Delta^{146} \mathrm{Nd}_{\text {clinopyroxene-wholerock }}=+0.047 \%\right.$ o $)$. Even with an extreme amount of fractionation of solely clinopyroxene (up to $40 \%$ ), which is rather unrealistic and not consistent with major element compositions of the gabbros, the lightest melt produced only has a $\delta^{146} \mathrm{Nd}$ of $-0.048 \%$ which is significantly less than the range preserved in Hole $735 \mathrm{~B}$ (Figure 10). Plagioclase probably also has a role to play in the evolution of the melts in Hole 735B. Given the lack of direct 

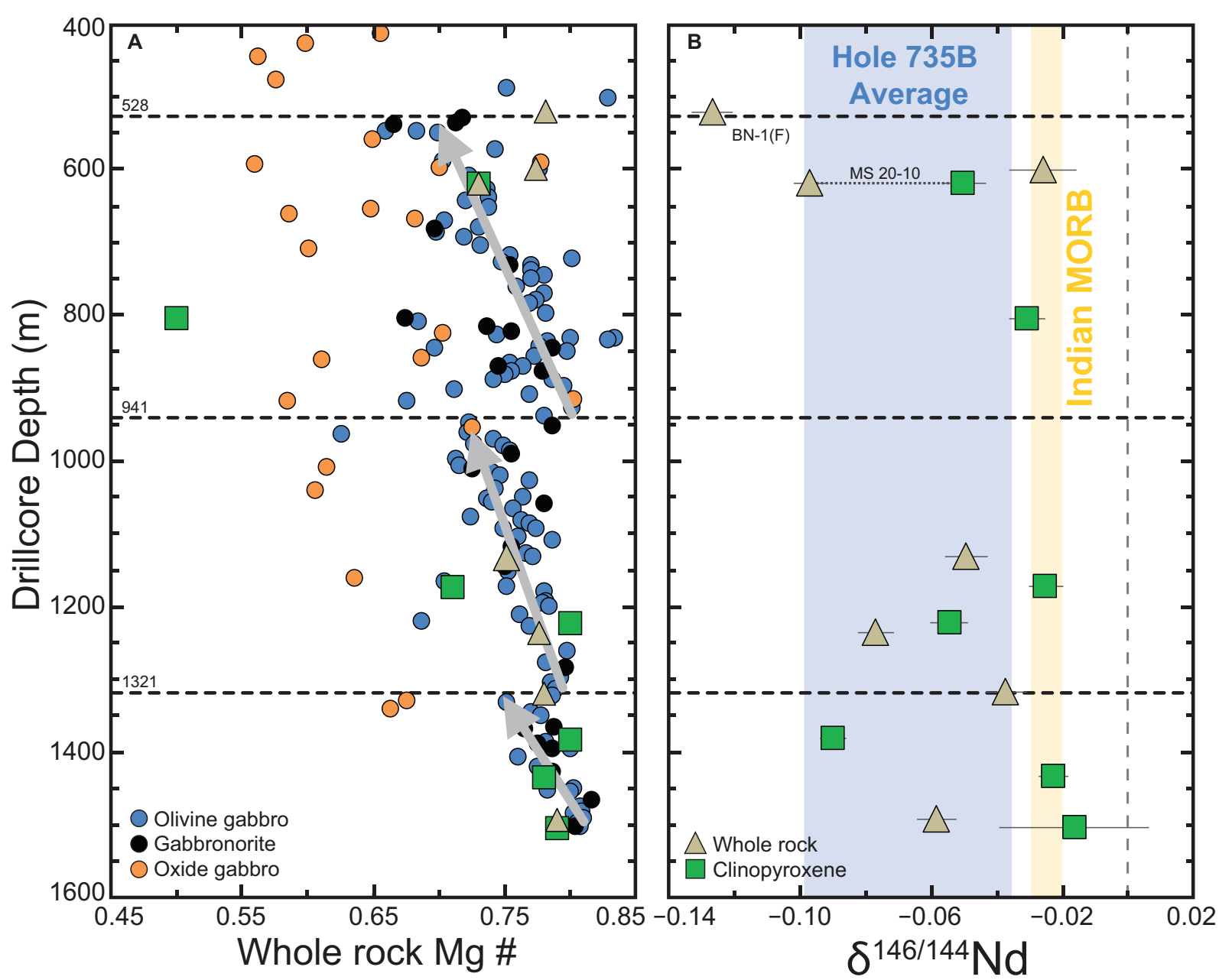

FIGURE 8 | Compositional variation in gabbroic rocks from Hole 735B relative to sampling depth. (A) Plot of whole rock Mg\# relative to drill core depth. Major element data for the samples herein is from Niu et al. (2002) and Bach et al. (2001) with comparative data taken from Dick et al. (1999), for clarity only the three major rock types are plotted. Dotted lines at 528, 941, and $1321 \mathrm{~m}$ represent major mineralogical discontinues identified in Dick et al. (2002) thought to delineate separate gabbro bodies. (B) Graph of $\delta^{146} \mathrm{Nd}$ in gabbroic rocks and clinopyroxene separates relative to sample depth. The yellow shaded area shows the average for Indian MORB $(-0.025 \pm 0.005 \%$; 95\% SE) with the blue field the average composition of Hole $735 \mathrm{~B}(-0.067 \pm 0.033 \%$ ).

measurements of this phase, we can merely make an educated assumption based on stable isotope principles. Based on $\mathrm{Nd}$ coordination in plagioclase $\left({ }^{V I} \mathrm{Nd}\right)$ and silicate melts $\left({ }^{V I} \mathrm{Nd}\right.$ or ${ }^{V I I} \mathrm{Nd}$ ) it would be predicted that plagioclase should have $\delta^{146} \mathrm{Nd}$ identical or slightly heavier than the melt. If the two phases occur in subequal proportions (as shown in Figure 6B) due to the difference in incompatibly, plagioclase will account for only about $1 / 5$ th of the total Nd of the rock. Therefore, even if $\mathrm{Nd}$ occurs in sevenfold coordination in melts and

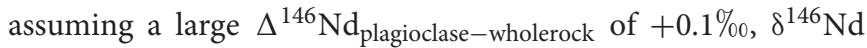
will change more rapidly but does not differ significantly from the pure clinopyroxene model already discussed (Figure 10). Ultimately, accumulation or fractionation of a mixture of clinopyroxene and plagioclase in subequal proportions is not capable of explaining the wide range of $\delta^{146} \mathrm{Nd}$ observed in Hole 735B gabbros instead disequilibrium processes are probably required.

\section{Evidence for Reactive Porous Flow}

The complicated histories preserved in plutonic rocks, collected from the three main ocean basins, have been used to propose that RPF is a nearly ubiquitous feature of the lower oceanic crust (e.g., Lissenberg and MacLeod, 2016). Complex zoning profiles, frozen mineral reaction textures, and mineral compositions and proportions that do not imitate models of simple fractional crystallization suggest that additional processes must have been involved in the formation of oceanic gabbros (Meyer et al., 1989; Coogan et al., 2000; Dick et al., 2002; Gao et al., 2007; Lissenberg and Dick, 2008; Lissenberg et al., 2013). RPF has been widely recognized through the over-enrichment of very to moderately incompatible trace elements in clinopyroxene (e.g., Ce/Y; see Figure 5 in Lissenberg and MacLeod, 2016), and poor correlations between mineral compositions and fractionation indices (e.g., elevated $\mathrm{TiO}_{2}$ contents in clinopyroxene; see Figure 5 in Lissenberg and Dick, 2008). 
TABLE 2 | Neodymium concentrations and isotopic compositions of gabbros and clinopyroxene separates from Hole 735B on the southwest Indian Ridge.

\begin{tabular}{|c|c|c|c|c|c|c|c|c|c|c|}
\hline Sample ID & $\begin{array}{l}\text { Rock } \\
\text { type }\end{array}$ & $\begin{array}{l}\text { Depth } \\
\text { (mbsf) }\end{array}$ & $\begin{array}{r}\text { Nd } \\
(\mathrm{ppm})\end{array}$ & ${ }^{143} \mathrm{Nd} /{ }^{144} \mathrm{Nd}$ & $\varepsilon \mathbf{N d}$ & $\delta^{146 / 144} \mathrm{Nd}$ & $\delta^{148 / 144} \mathrm{Nd}$ & $\delta^{146 / 144} \mathrm{Nd}_{\text {NORM }}$ & 2 SD & $n$ \\
\hline \multicolumn{11}{|c|}{ Gabbro whole rocks } \\
\hline $\mathrm{BN}-1(\mathrm{~F})$ & OG & 521.2 & 1.39 & $0.513133 \pm 4$ & 9.65 & $-0.123 \pm 0.006$ & $-0.213 \pm 0.012$ & $-0.127 \pm 0.006$ & & \\
\hline $\mathrm{BN}-5(\mathrm{~F})$ & OG & 599.6 & 2.01 & $0.513125 \pm 5$ & 9.49 & $-0.007 \pm 0.010$ & $-0.010 \pm 0.020$ & $-0.026 \pm 0.010$ & & \\
\hline MS 20-10 & OxG & 619.3 & 1.70 & $0.512987 \pm 3$ & 6.81 & $-0.093 \pm 0.005$ & $-0.208 \pm 0.010$ & $-0.097 \pm 0.005$ & & \\
\hline $\mathrm{BN}-10(\mathrm{~F})$ & OG & 1133.0 & 4.23 & $0.513131 \pm 4$ & 9.61 & $-0.046 \pm 0.006$ & $-0.070 \pm 0.012$ & $-0.049 \pm 0.006$ & & \\
\hline $\mathrm{BN}-14(\mathrm{~F})$ & OG & 1235.8 & 3.42 & $0.513134 \pm 3$ & 9.68 & $-0.073 \pm 0.005$ & $-0.179 \pm 0.011$ & $-0.077 \pm 0.006$ & & \\
\hline MS 84-28 & DOXOG & 1319.0 & 1.45 & $0.513137 \pm 3$ & 9.73 & $-0.034 \pm 0.006$ & $-0.084 \pm 0.012$ & $-0.037 \pm 0.006$ & & \\
\hline \multirow[t]{3}{*}{$\mathrm{BN}-2 \mathrm{O}(\mathrm{F})$} & OG & 1494.4 & 1.34 & $0.513116 \pm 3$ & 9.33 & $-0.039 \pm 0.005$ & $-0.112 \pm 0.010$ & $-0.058 \pm 0.006$ & & \\
\hline & & & & & $9.29 \pm 1.22^{\star}$ & & Average-Gabbro: & $-0.067 \pm 0.033$ & \pm 0.071 & 7 \\
\hline & & & & & & \multicolumn{2}{|c|}{ Oceanic Crust Weighted Average: } & -0.064 & & \\
\hline
\end{tabular}

\section{Clinopyroxene separates}

\begin{tabular}{|c|c|c|c|c|c|c|c|c|c|c|}
\hline MS 20-10 & OxG & 619.3 & 8.63 & $0.513138 \pm 4$ & 9.76 & $-0.047 \pm 0.006$ & $-0.109 \pm 0.013$ & $-0.050 \pm 0.007$ & & \\
\hline MS 41-18 & $O x O G$ & 803.7 & 80.94 & $0.513125 \pm 2$ & 9.51 & $-0.027 \pm 0.005$ & $-0.066 \pm 0.010$ & $-0.031 \pm 0.006$ & & \\
\hline MS 70-20 & OGN & 1173.0 & 13.31 & $0.513128 \pm 3$ & 9.55 & $-0.022 \pm 0.005$ & $-0.029 \pm 0.010$ & $-0.025 \pm 0.005$ & & \\
\hline MS 78-25 & OxG & 1222.9 & 5.05 & $0.513109 \pm 3$ & 9.19 & $-0.051 \pm 0.006$ & $-0.115 \pm 0.011$ & $-0.055 \pm 0.006$ & & \\
\hline MS 93-35 & OG & 1382.7 & 3.83 & $0.513140 \pm 2$ & 9.80 & $-0.086 \pm 0.003$ & $-0.192 \pm 0.007$ & $-0.090 \pm 0.004$ & & \\
\hline MS 95-34 & $D O x G$ & 1434.2 & 2.83 & $0.513113 \pm 2$ & 9.27 & $-0.019 \pm 0.004$ & $-0.045 \pm 0.008$ & $-0.023 \pm 0.005$ & & \\
\hline \multirow[t]{2}{*}{ MS 101-38^ } & OxOGN & 1504.6 & 3.73 & $0.513139 \pm 14$ & 9.78 & $-0.013 \pm 0.023$ & - & $-0.016 \pm 0.023$ & & \\
\hline & & & & & & \multicolumn{2}{|c|}{ Average-Clinopyroxene: } & $-0.041 \pm 0.024$ & \pm 0.051 & 7 \\
\hline
\end{tabular}

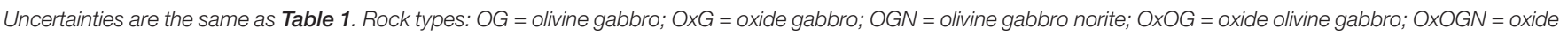

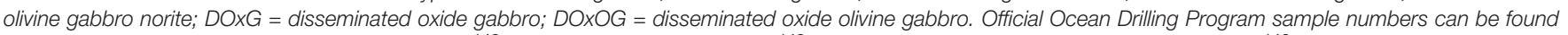

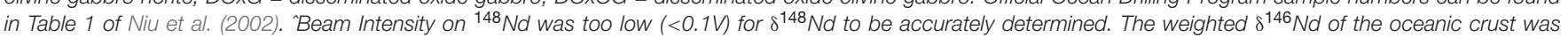

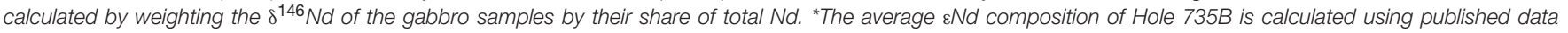
( $n$ = 72; Kempton et al., 1991; Hart et al., 1999; Holm, 2002; herein).

Lissenberg and Dick (2008) presented a frozen example of RPF from the Kane Megamullion (mid-Atlantic Ridge), where ca. $5 \mathrm{~cm}$ wide channels of coarse-grained gabbro crosscuts a medium grained troctolite host rock. Percolation of clinopyroxene-saturated melt through the troctolite (Eq. 2), led to the dissolution of olivine, plagioclase (partial) and Cr-spinel in the troctolite and crystallization of high $\mathrm{Mg \#}$ clinopyroxene and lower-anorthite plagioclase.

$$
\begin{gathered}
\text { Olivine }+ \text { plagioclase } 1+\mathrm{Cr}-\text { spinel }+ \text { melt } 1 \\
=\text { clinopyroxene }+ \text { plagioclase } 2+\text { melt } 2
\end{gathered}
$$

Strong petrographic evidence is preserved that RPF has occurred widely in gabbros collected from the Atlantis Bank including: (1) textural evidence for the reaction of clinopyroxene with melt is preserved (i.e., complexly intergrown and ragged clinopyroxene grain boundaries); (2) troctolite-to-olivine gabbro reactions have been observed in the Hole $735 \mathrm{~B}$ gabbros (see Figure 8 in Lissenberg and MacLeod, 2016); (3) significant core to rim enrichments of incompatible trace elements are preserved in clinopyroxene (Meyer et al., 1989; Kvassnes, 2004; Gao et al., 2007; Lissenberg and MacLeod, 2016); and (4) the composition of major silicate phases is poorly correlated with the evolution of the main gabbro bodies, instead a wide range in minor element concentrations (both compatible and

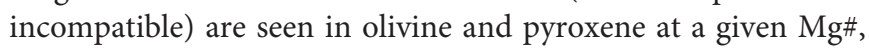

consistent with widespread permeable flow of late-stage melt through these intrusions (Dick et al., 2002). Clinopyroxene with $\mathrm{TiO}_{2}$ contents $>0.3$ wt $\%$ cannot be generated by fractional crystallization of a primitive MORB magma and instead have been interpreted to reflect RPF (Lissenberg and Dick, 2008; Lissenberg and MacLeod, 2016). A negative correlation is observed between $\delta^{146} \mathrm{Nd}$ in clinopyroxene and the $\mathrm{TiO}_{2}$ of the clinopyroxene for samples from Hole 735B (Figure 11), consistent with increasing amounts of RPF producing isotopically light clinopyroxene. Furthermore, when the clinopyroxene separates are plotted on the Cpx\# versus $\delta^{146} \mathrm{Nd}$ graph (Figure 6B), they are generally heavier, but variably offset from the well-defined whole rock trend consistent with a disequilibrium process where each individual sample is affected uniquely.

Given the multi-faceted evidence for RPF in Hole 735B next we explore the effects of this process on $\delta^{146} \mathrm{Nd}$ values. The preservation of highly fractionated isotopic signatures in minerals is a widespread phenomenon and can arise because of diffusion during crystal growth or through entrainment of crystals that are not in equilibrium with a melt (e.g., Lundstrom et al., 2005; Weyer and Ionov, 2007; Sio et al., 2013; McCoy-West et al., 2018). When kinetic isotope fractionation occurs light isotopes will preferentially diffuse faster than heavier ones (e.g., Richter et al., 2009), although diffusion in a medium is also dependent on temperature, pressure, 

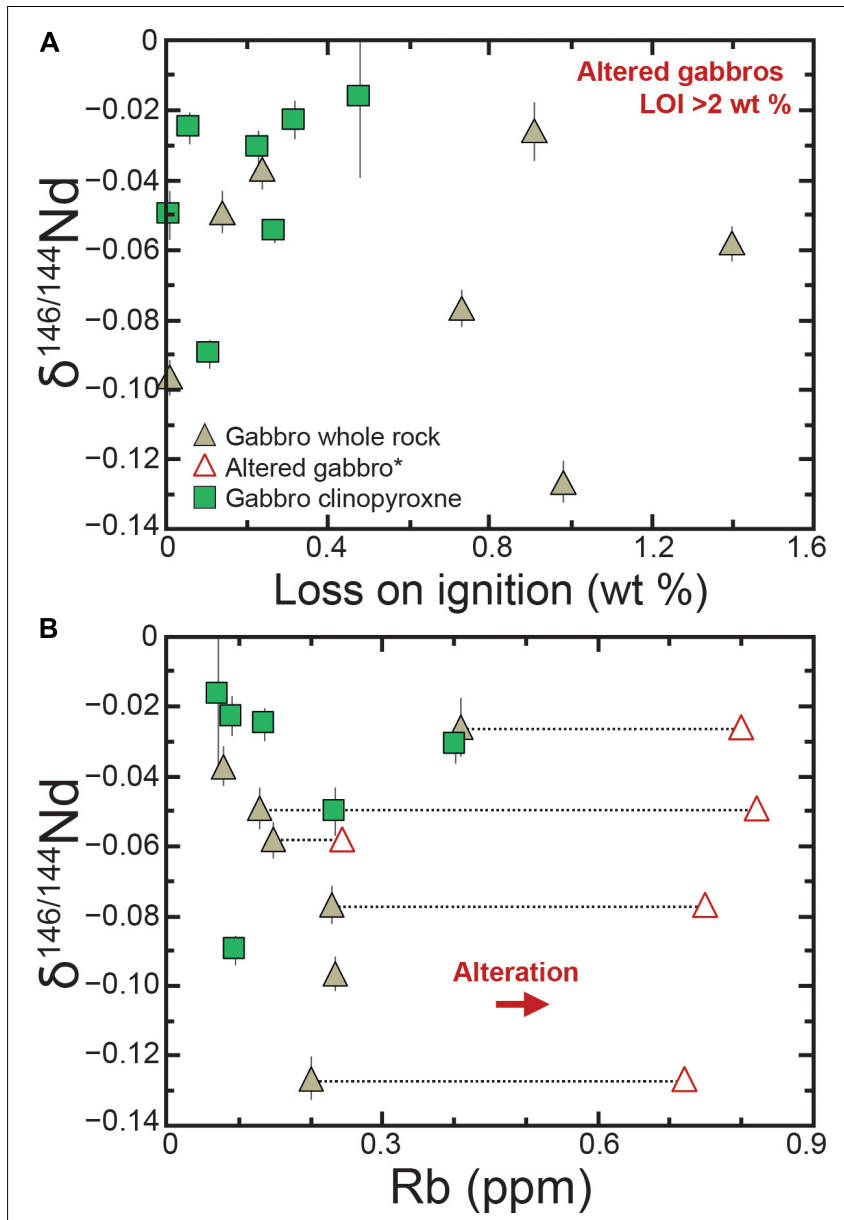

FIGURE 9 | Graphs of $\delta^{146} \mathrm{Nd}$ against loss on ignition (A) and whole rock rubidium concentration (B), respectively. Clinopyroxenes separates are plotted at the compositional values of their whole rock. Comparative data comes from Bach et al. (2001) and Niu et al. (2002). (B) Altered samples are plotted at the $\delta^{146} \mathrm{Nd}$ of their equivalent unaltered sample. Significant enrichment of large ion lithophile elements, such as $\mathrm{Rb}$ occurs during alteration as the result of clay formation (e.g., smectite; Staudigel et al., 1981).

chemical composition and the spatial anisotropy of the medium (Watkins et al., 2017). In silicate melts, the ratio of the diffusivities of two isotopes $\left(\mathrm{D}^{r e l}\right)$ of the same element have been shown to depend on their masses Richter et al. (2003):

$$
D^{r e l}=\frac{D_{H}}{D_{L}}=\left(\frac{m_{L}}{m_{H}}\right)^{\beta}
$$

where $D_{\mathrm{H}}$ and $D_{\mathrm{L}}$ are the diffusivities of the heavy and light isotopes, respectively, $\beta$ is a dimensionless empirical parameter allowing comparison between different elements, and $m_{\mathrm{H}}$ and $m_{\mathrm{L}}$ are their masses (in this instance 145.91313 and 143.9101, respectively). Given there is currently no theoretical basis for predicting the value of the $\beta$ exponent it must be determined experimentally (Watson and Müller, 2009). Unfortunately experiments for $\mathrm{Nd}$ do not exist, however, the experimental determined values of $\beta$ in silicate melts for

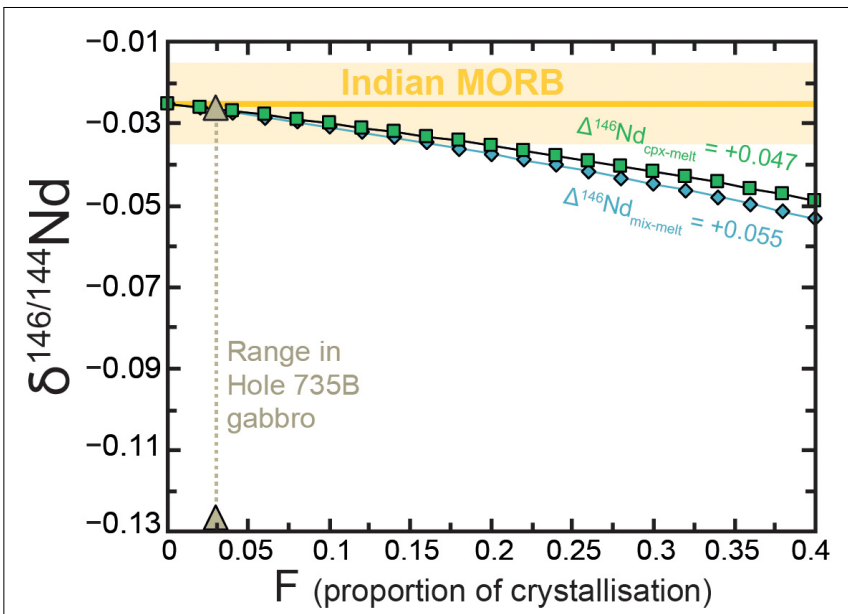

FIGURE 10 | Rayleigh fractionation model showing the evolution of $\delta^{146} \mathrm{Nd}$ from fractional crystallization. Modeling assumes an initial $\delta^{146} \mathrm{Nd}$ of $-0.025 \%$ based on Indian MORB, although this value is also within uncertainty of most global magmas and chondrites (see Figure 3). A clinopyroxene crystallization

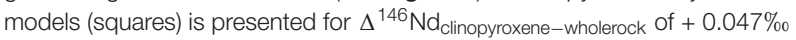
(as observed in sample MS 20-10). A mixed assemblage model (diamonds) comprising $50 \%$ clinopyroxene and $50 \%$ plagioclase is also shown. This model uses the proportion of total $\mathrm{Nd}$ in the two phases (83.3\% cpx; $16.7 \%$ plag) calculated assuming $D_{\mathrm{cpx}}=0.5$ and $D_{\text {plag }}=0.1$ and assuming $\delta^{146} \mathrm{Nd}_{\mathrm{cpx}}=0.021 \%$ and $\delta^{146} \mathrm{Nd}$ plag $=0.075 \%$. Even following significant amounts of crystallization ( $F=0.4 ; 40 \%$ ) it is not possible to reproduce the wide range of variation in $\delta^{146} \mathrm{Nd}$ observed in the Hole 735B gabbros.

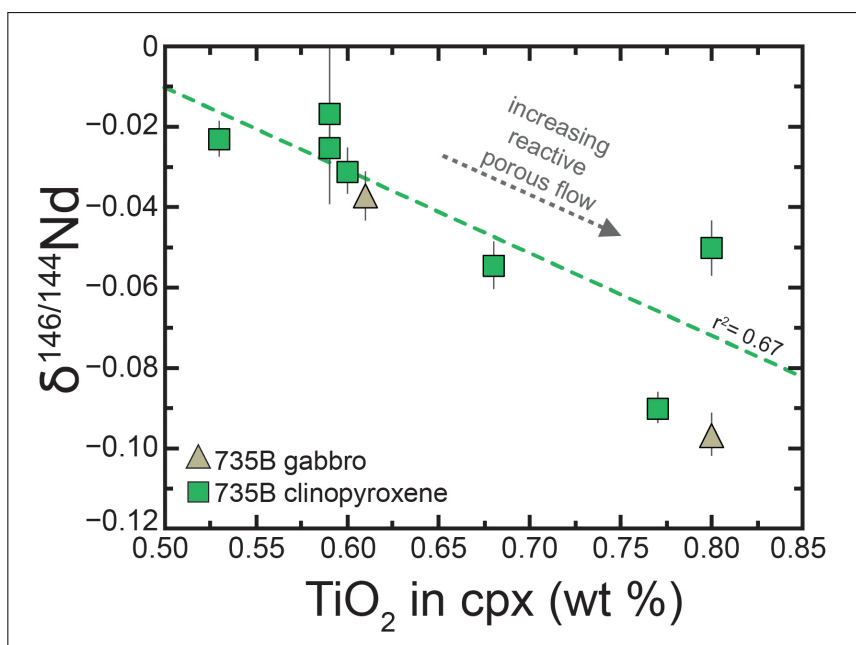

FIGURE 11 | Relationship between the $\mathrm{TiO}_{2}$ content of clinopyroxene and $\delta^{146} \mathrm{Nd}$ in Hole 735B. Clinopyroxene major element data is only available for two of the whole rock gabbro samples (Niu et al., 2002). $\mathrm{TiO}_{2}$ contents $>0.3$ $w t \%$ are considered to result from reactive porous flow. A strong negative correlation is observed between $\delta^{146} \mathrm{Nd}$ and the $\mathrm{TiO}_{2}$ of the clinopyroxene, consistent with increased amounts of reactive porous flow producing isotopically lighter clinopyroxene.

heavier elements possess an extremely restricted range of $0.03-$ 0.07 (Ca, Mg, Fe; Watkins et al., 2017). When modeling diffusion during crystal growth two assumptions are made: (1) the surface of the mineral is in equilibrium with the 

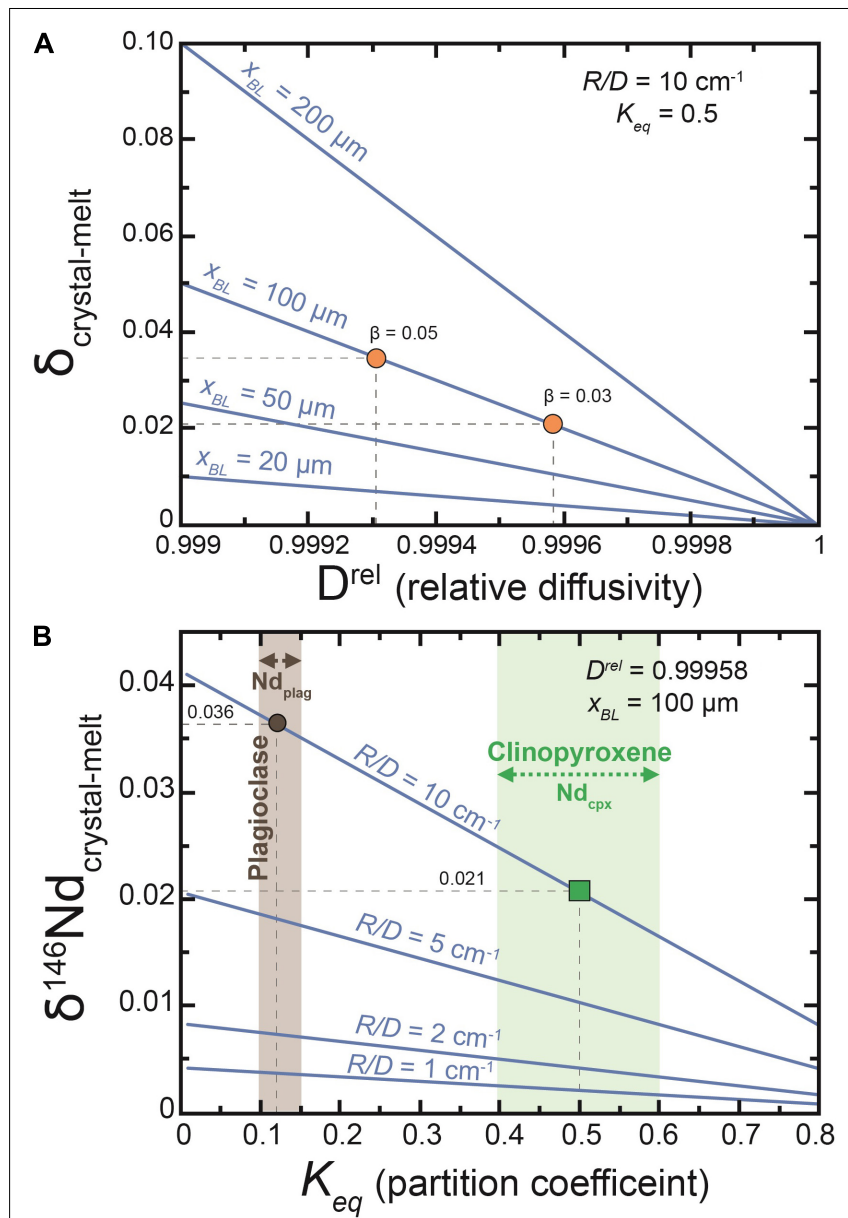

FIGURE 12 | Diffusion modeling showing the maximum kinetic isotope fractionation predicted in a growing crystal. (A) The magnitude of isotope fractionation is proportional to both the thickness of the diffusive boundary layer $\left(x_{\mathrm{BL}}\right)$ and the relative diffusivity of the two isotopes of interest $\left(D^{r e l}=D_{\mathrm{H}} / D_{\mathrm{L}}\right)$. Circles show the calculated $D^{r e l}$ for $\mathrm{Nd}$ based on assuming a $\beta$ factor for the system of 0.03 and 0.05 . (B) The magnitude of isotopic fractionation is proportional to the rate of crystal growth $(R)$ relative to the diffusivity in the medium $(D)$. By making geological reasonable assumptions it is possible to estimate the likely kinetic isotope fractionation in the major $\mathrm{Nd}$ hosts of the gabbros (clinopyroxene and plagioclase).

fluid at the solid-fluid interface and (2) that diffusion in the solid is negligible (which is valid given $\mathrm{Nd}$ diffusion in clinopyroxene and plagioclase is extremely slow; Van Orman et al., 2001; Cherniak, 2003). Therefore, any kinetic effect isotope fractionation occurs due to diffusion in the melt. Albarede and Bottinga (1972) introduced the concept of diffusive boundary layers showing that in fast growing crystals the uptake of impurities can diverge significantly from equilibrium, with the key parameter being the ratio of the growth rate to the diffusivity of the impurity $(R / D$; Figure 12). The kinetic uptake of REE impurities is more efficient when grain sizes are larger, or when a high melt flux moves through a region (Van Orman et al., 2002) making gabbros in the lower oceanic crust an ideal location for this process to occur.
Watson and Müller (2009) developed a simple expression that calculates the maximum kinetic isotope fractionation in a growing crystal that would occur prior to the system reaching steady-state:

$$
\delta=1000 \times\left(1-\frac{D_{H}}{D_{L}}\right) \times\left(\frac{R \cdot x_{B L}}{D_{H}}\right) \times\left(1-K_{e q}\right)
$$

where $\delta$ is the deviation from equilibrium in parts per thousand. $R$ is the growth rate of the crystal (in $\mathrm{cms}^{-1}$ ), $K_{\mathrm{eq}}$ is the equilibrium partition coefficient between the crystal and the growth medium, and $x_{\mathrm{BL}}$ is thickness of the boundary layer. The magnitude of isotope fractionation is proportional to both the thickness of the diffusive boundary layer and the relative diffusivity $\left(\mathrm{D}^{r e l}\right)$ of the two isotopes of interest which is dependent on the $\beta$ factor for the system (Figure 12A). By assuming the diffusive boundary layer is $100 \mu \mathrm{m}$ thick, the maximum observed in silicate systems (Kerr, 1995), and using the minimum experimentally determined $\beta$ factor (i.e., $\beta_{\mathrm{Nd}}=\beta_{\mathrm{Fe}}=0.03$; Richter et al., 2009) we can explore the size of fractionations in $\delta^{146} \mathrm{Nd}$ which can be ascribed to RPF (Figure 12B). This modeling shows that for a given crystal growth rate, larger isotopic fractionations are predicted when $\mathrm{Nd}$ is more incompatible in a phase, and minimal fractionation is predicted at $R / D<1$. Assuming an $R / D$ of 10 , which is at the upper end of values for phenocryst growth (Orlando et al., 2008; Maaløe, 2011), kinetic isotope fractionations of ca. 0.021 and $0.036 \%$ are predicted in clinopyroxene and plagioclase, respectively. A strong negative correlation is observed between $\delta^{146} \mathrm{Nd}$ and the modal proportion of clinopyroxene in Hole $735 \mathrm{~B}$ gabbros (Figure 6B). For kinetic process to explain this correlation would require that the extremely isotopically light gabbros represent quenched melts that have lost a proportion of their heavy isotopes during RPF in a different region of the lower crust (melt migration is observed at least on the short length scales in Hole 735B). Natland and Dick (2001) suggested that these gabbroic cumulates formed in a dense crystal mush dominated by fractures, channelized flow and intergranular porous flow which is the ideal environment to generate kinetic isotope fractionations. The mechanism responsible for generating variations in $\delta^{146} \mathrm{Nd}$ is clearly not straightforward, with the sample with the lightest $\delta^{146} \mathrm{Nd}$ clearly not adhering to this correlation $[\mathrm{BN}-1(\mathrm{~F})=-0.127 \%$ ]. However, this sample was collected at 521 mbsf, within a region that contains several distinct lithostragraphic units, and within $10 \mathrm{~m}$ of a major boundary between distinct two gabbro bodies (Figure 8). This region probably experienced more concentrated melt flow aiding in the dissolution and reprecipitation of isotopic signatures at grain boundaries. Given the small magnitude of isotopic fractionation predicted in Figure 12, for RPF alone to account for the $\delta^{146} \mathrm{Nd}$ variations observed in Hole $735 \mathrm{~B}$ gabbros one of the following is required: (1) crystal growth rates during this process are higher than previous recognized; (2) the $\beta$ value for $\mathrm{Nd}$ is higher than the minimum experimentally determined value used for the predictions; or (3) several cycles of RPF are required to generated the extreme isotope compositions of some the gabbros. Further experimental work is required to better 
understand this process. Given the unrivaled complexity of the oceanic curst at slow spreading ridges it is fitting that no single process can conclusively explain the variability observed instead a combination of several processes is probably required.

\section{Reconciling the Disconnect Between the Composition of the Oceanic Crust and Overlying MORB}

\section{The Homogenous $\delta^{146} \mathrm{Nd}$ of MORB}

The large variations observed in $\delta^{146} \mathrm{Nd}$ in the gabbroic rocks of Hole $735 \mathrm{~B}$ are distinctly different than erupted Indian MORB which possesses a very restricted range of $\delta^{146} \mathrm{Nd}$ from -0.015 to $-0.029 \%$ (Figure 3). The average composition of Indian MORB is $\delta^{146} \mathrm{Nd}=-0.025 \pm 0.010 \%$ (Figure 8), which is identical within uncertainty to the composition of Pacific MORB (Figure 3) and the global MORB average of $-0.024 \pm 0.013 \%$ (Table 1). In contrast, available mantle peridotite data display a significantly wider range of $\delta^{146} \mathrm{Nd}$ with values ranging from -0.045 to $+0.029 \%$ (McCoy-West et al., 2017). These peridotites have significantly lower $\mathrm{Nd}$ concentrations (0.10-0.81 ppm; McCoy-West et al., 2020) than erupted MORB and comprise samples from a variety of tectonic settings, therefore, several processes may be responsible for their variable $\delta^{146} \mathrm{Nd}$ including, but not limited to, partial melting, melt metasomatism, and mineralogical variations. In the MORB dataset no correlations are observed between $\delta^{146} \mathrm{Nd}$ and $\mathrm{Nd}$ radiogenic isotope compositions (Figure 4B), showing that mantle source heterogeneity and the process of formation are effectively decoupled. Given that $\delta^{146} \mathrm{Nd}$ is process dependent this means any initial variations in the $\delta^{146} \mathrm{Nd}$ of the source material need not be transferred to the final MORB, with the indistinguishable $\delta^{146} \mathrm{Nd}$ of global MORB suggesting that these magmas have been homogenized through the same global process. Partial melting concentrates Nd into the melt phase (modeling suggests that with only $10 \%$ melting $>80 \%$ of the original $\mathrm{Nd}$ budget will be in the melt fraction; McCoyWest et al., 2015) helping effectively eliminate small scale heterogeneities from the source region. Further processing in the extensive magma chamber network observed at mid-ocean ridge systems globally, would be an ideal place to form such a homogenous reservoir. These magma chambers are required to be open systems to explain the trace element over-enrichment of MORB (O'Hara, 1977; Jenner and O'Neill, 2012), and therefore are constantly replenished with new melt providing an ideal mechanism to homogenize the $\delta^{146} \mathrm{Nd}$ of the magmas. Amongst the novel stable isotopes systems $\mathrm{Nd}$ appears unique with small heterogeneities greater than analytical precision observed for many other isotopic systems including $\mathrm{Fe}, \mathrm{Mo}, \mathrm{Ba}$ (Teng et al., 2013; Bezard et al., 2016; Nielsen et al., 2018). It will be interesting if the homogeneity of the MORB reservoir is confirmed when new data becomes available.

\section{Can the Melts in the Oceanic Crust Generate MORB in the SWIR?}

The discussion above shows that to produce the extremely light values observed in Hole 735B gabbros requires some level of
RPF. Advocates of RPF also suggest that this mechanism is responsible for the geochemical variability observed in erupted MORB glasses (e.g., Lissenberg and Dick, 2008; Lissenberg and MacLeod, 2016). Meaning that MORB magmas and gabbros in the oceanic crust should directly complement each other. There are several lines of evidence that suggest this is not the case for the samples from the SWIR: (1) there is a significant disconnect between the major element composition of MORB magmas and the lower oceanic crust with MORB glasses being significantly more evolved than the bulk composition of Hole $735 \mathrm{~B}$, whereas they should be the complimentary melts of the preserved oceanic crust (i.e., Mg\#; Figure 6A). Furthermore, the average composition of the crust at Hole 735B is not sufficiently primitive in terms of $\mathrm{Mg} \#$ or highly compatible trace element concentrations (e.g., $\mathrm{Ni}$ ) for the bulk crust to be in equilibrium with the mantle (Coogan et al., 2001); (2) Hole 735B is largely comprised of cumulate gabbros (Dick et al., 2000; Natland and Dick, 2001). Despite significant $\mathrm{Sr}$ and Eu anomalies (from plagioclase accumulation) being observed in individual samples (1-4 m length scale), the average composition of the complete upper $500 \mathrm{~m}$ section of the Hole $735 \mathrm{~B}$ displays no significant $\mathrm{Sr}$ or $\mathrm{Eu}$ anomalies $(\leq 1 \%)$, this implies that there has been local separation of melt and solids, but no large scale removal of melts into the upper crust (Hart et al., 1999); and (3) stable $\mathrm{Nd}$ isotope compositions also suggest a significant disconnect between the lower oceanic crust and MORB compositions. The calculated average composition of the gabbro whole rocks is $\delta^{146} \mathrm{Nd}=-0.067 \pm 0.033 \%$ (95\% SE), with the weighted average based on the proportion of $\mathrm{Nd}$ in each sample being almost an identical $-0.064 \%$ (Table 2). This large isotopic discrepancy makes it very unlikely that significant melt has escaped the lower oceanic crust, and for the SWIR at least oceanic gabbros that have experienced RPF have had little impact on the compositions of erupted MORB.

\section{CONCLUSIONS}

Stable isotope compositions are process dependent and therefore provide an excellent mechanism to compare contrasting petrogenetic models. Here, we present the first neodymium stable isotope compositions of Indian Ocean MORB glass and gabbro whole rock and clinopyroxene separates from ODP Hole 735B on the SWIR which show:

(1) Mid-ocean ridge basalts are extremely homogenous with the average $\delta^{146} \mathrm{Nd}$ of Indian MORB of $-0.025 \pm 0.005 \%$, identical within uncertainty to the global average of $-0.024 \pm 0.004 \%$. Despite significant variability in the source composition of MORB magmas globally (i.e., ${ }^{143} \mathrm{Nd} /{ }^{144} \mathrm{Nd}$ ) their indistinguishable $\delta^{146} \mathrm{Nd}$ suggests that any mantle source heterogeneities in $\delta^{146} \mathrm{Nd}$ are overprinted during the process of their formation. The extensive magma chamber at mid-ocean ridge systems globally, that are constantly replenished with new Ndenriched melt, provide the ideal location to form such a homogenous reservoir. 
(2) In Hole $735 \mathrm{~B}$ the $\delta^{146} \mathrm{Nd}$ of gabbroic rocks is highly variable ranging from -0.026 to $-0.127 \%$. Clinopyroxene separates also possess variable $\delta^{146} \mathrm{Nd}\left(\delta^{146} \mathrm{Nd}=74 \mathrm{ppm}\right)$ but are variably offset to heavier values than the gabbro whole rocks at the same major element composition, with a $\Delta^{146} \mathrm{Nd}_{\text {clinopyroxene-wholerock }}$ of $+0.047 \%$ observed in one paired sample.

(3) Rayleigh fractionation modeling shows fractionation of isotopically heavy clinopyroxene \pm plagioclase has a limited effect on $\delta^{146} \mathrm{Nd}$ even after significant fractional crystallization $(F=40 \%)$. Therefore, the large variations in $\delta^{146} \mathrm{Nd}$ observed in the oceanic gabbros cannot be generated solely by the fractionation or accumulation of magmatic minerals.

(4) Strong evidence exists to support RPF in Hole 735B, a process which will induce kinetic isotope fractionation during crystal growth. However, diffusion modeling based on geologically reasonable parameters, shows that minimal kinetic isotope fractionation ca. $0.02 \%$ will be induced in clinopyroxene. Thus, to produce the extremely light $\delta^{146} \mathrm{Nd}$ values observed in the gabbros would require multiple cycles of dissolution and reprecipitation of isotopic signatures at grain boundaries.

(5) In Hole 735B there is a large offset, significantly greater than analytical uncertainty, between the average composition of the lower oceanic crust $\left(\delta^{146} \mathrm{Nd}=-0.067 \%\right)$ and erupted Indian MORB $\left(\delta^{146} \mathrm{Nd}=-0.025 \% 0\right)$. Combined with the geochemical evidence (e.g., Sr and $\mathrm{Eu}$ anomalies) for no large-scale removal of melts into the upper crust we conclude that melts involved in RPF have no significant impact on the $\mathrm{Nd}$ stable isotope composition of MORB erupted at the

\section{REFERENCES}

Albarede, F., and Bottinga, Y. (1972). Kinetic disequilibrium in trace element partitioning between phenocrysts and host lava. Geochim. Cosmochim. Acta 36, 141-156. doi: 10.1016/0016-7037(72)90003-90008

Bach, W., Alt, J. C., Niu, Y., Humphris, S. E., Erzinger, J., and Dick, H. J. B. (2001). The geochemical consequences of late-stage low-grade alteration of lower ocean crust at the SW Indian Ridge: results from ODP Hole 735B (Leg 176). Geochim. Cosmochim. Acta 65, 3267-3287. doi: 10.1016/S0016-7037(01)00677-679

Baines, A. G., Cheadle, M. J., John, B. E., Grimes, C. B., Schwartz, J. J., and Wooden, J. L. (2009). SHRIMP Pb/U zircon ages constrain gabbroic crustal accretion at Atlantis Bank on the ultraslow-spreading Southwest Indian Ridge. Earth Planet. Sci. Lett. 287, 540-550. doi: 10.1016/j.epsl.2009.09.002

Baines, A. G., Cheadle, M. J., Dick, H. J. B., Scheirer, A. H., John, B. E., Kusznir, N. J., et al. (2007). Evolution of the Southwest Indian Ridge from $55^{\circ} 45^{\prime} \mathrm{E}$ to $62^{\circ} \mathrm{E}$ : changes in plate-boundary geometry since $26 \mathrm{Ma}$. Geochemi.Geophys.Geosyst. 8, doi: 10.1029/2006GC001559

Bau, M. (1991). Rare-earth element mobility during hydrothermal and metamorphic fluid-rock interaction and the significance of the oxidation state of europium. Chem. Geol. 93, 219-230. doi: 10.1016/0009-2541(91)9011590118

Bédard, J. H. (2014). Parameterizations of calcic clinopyroxene-Melt trace element partition coefficients. Geochem.Geophys., Geosyst. 15, 303-336. doi: 10.1002/2013GC005112

Bennett, V. C., Brandon, A. D., and Nutman, A. P. (2007). Coupled 142Nd-143Nd isotopic evidence for Hadean mantle dynamics. Science 318:1907. doi: 10.1126/ science. 1145928
SWIR. Whether this conclusion is a global phenomenon remains to be tested.

\section{DATA AVAILABILITY STATEMENT}

All datasets generated for this study are included in the article/supplementary material.

\section{AUTHOR CONTRIBUTIONS}

AM-W and $\mathrm{KB}$ conceived the study. AM-W and M-AM developed the double spike. AM-W undertook the chemistry and mass spectrometry, and wrote the manuscript with input from all the authors.

\section{FUNDING}

This project was funded by a National Environmental Research Council (United Kingdom) Grant (NE/N003926/1) to KB. While at Monash AM-W was supported by ARC grant FL160100168 to Peter Cawood.

\section{ACKNOWLEDGMENTS}

Yaoling Niu is thanked for generously providing the samples. AM-W thanks Peter Cawood for the freedom to complete this work. Geoff Nowell for the knowledge of mass spectrometry he imparted during my time at Durham. Priyadarshini Chowdhury for discussions about diffusion.

Bezard, R., Fischer-Gödde, M., Hamelin, C., Brennecka, G. A., and Kleine, T. (2016). The effects of magmatic processes and crustal recycling on the molybdenum stable isotopic composition of Mid-Ocean Ridge Basalts. Earth Planet. Sci. Lett. 453, 171-181. doi: 10.1016/j.epsl.2016. 07.056

Bienvenu, P., Bougault, H., Joron, J. L., Treuil, M., and Dmitriev, L. (1990). MORB alteration: rare-earth element/non-rare-earth hygromagmaphile element fractionation. Chem Geol. 82, 1-14. doi: 10.1016/0009-2541(90)90 070-N

Bigeleisen, J., and Mayer, M. G. (1947). Calculation of equilibrium constants for isotopic exchange reactions. J. Chem. Phys. 15, 261-267. doi: 10.1063/1.1746492

Bindeman, I. N., and Davis, A. M. (2000). Trace element partitioning between plagioclase and melt: investigation of dopant influence on partition behavior. Geochim. Cosmochim Acta 64, 2863-2878. doi: 10.1016/S0016-7037(00)00 38-386

Bloomer, S. H., Meyer, P. S., Dick, H. J. B., Ozawa, K., and Natland, J. H. (1991). "Textural and mineralogic variations in gabbroic rocks from Hole 735B," in Proceedings. ODP, Sci. Results, eds R. Von Herzen, and P. T. Robinson, (College Station, TX: Ocean Drilling Program).

Burton, K. W., Cenki-Tok, B., Mokadem, F., Harvey, J., Gannoun, A., Alard, O., et al. (2012). Unradiogenic lead in Earth's upper mantle. Nat. Geosci. 5, 570-573. doi: $10.1038 /$ ncomms5474

Cherniak, D. J. (2003). REE diffusion in feldspar. Chem. Geol. 193, 25-41. doi: 10.1016/S0009-2541(02)00246-242

Coogan, L. A. (2014). "4.14 - the lower oceanic crust," in Treatise on Geochemistry, 2nd end, eds H. D. Holland, and K. K. Turekian, (Oxford: Elsevier), 497-541. doi: 10.1016/b978-0-08-095975-7.00316-8 
Coogan, L. A., MacLeod, C. J., Dick, H. J. B., Edwards, S. J., Kvassnes, A., Natland, J. H., et al. (2001). Whole-rock geochemistry of gabbros from the Southwest Indian Ridge: constraints on geochemical fractionations between the upper and lower oceanic crust and magma chamber processes at (very) slow-spreading ridges. Chem. Geol. 178, 1-22. doi: 10.1016/S0009-2541(00)00424-421

Coogan, L. A., and O'Hara, M. J. (2015). MORB differentiation: in situ crystallization in replenished-tapped magma chambers. Geochim. Cosmochim. Acta 158, 147-161. doi: 10.1016/j.gca.2015.03.010

Coogan, L. A., Thompson, G. M., MacLeod, C. J., Dick, H. J. B., Edwards, S. J., Hosford Scheirer, A., et al. (2004). A combined basalt and peridotite perspective on 14 million years of melt generation at the Atlantis Bank segment of the Southwest Indian Ridge: evidence for temporal changes in mantle dynamics? Chemi. Geol. 207, 13-30. doi: 10.1016/j.chemgeo.2004.01.016

Coogan, L. A., Saunders, A. D., Kempton, P. D., and Norry, M. J. (2000). Evidence from oceanic gabbros for porous melt migration within a crystal mush beneath the Mid-Atlantic Ridge. Geochem. Geophys., Geosyst. 1, doi: 10.1029/ 2000GC000072

Crisp, J. A. (1984). Rates of magma emplacement and volcanic output. J. Volcanol. Geotherm. Rese. 20, 177-211. doi: 10.1016/0377-0273(84)90039-90038

Dauphas, N., Roskosz, M., Alp, E. E., Neuville, D. R., Hu, M. Y., Sio, C. K., et al. (2014). Magma redox and structural controls on iron isotope variations in Earth's mantle and crust. Earth Planet. Sci. Lett. 398, 127-140. doi: 10.1016/j. epsl.2014.04.033

Detrick, R. S., Buhl, P., Vera, E., Mutter, J., Orcutt, J., Madsen, J., et al. (1987). Multichannel seismic imaging of a crustal magma chamber along the East Pacific Rise. Nature 326, 35-41. doi: 10.1038/326035a0

Dick, H. J. B., Fisher, R. L., and Bryan, W. B. (1984). Mineralogic variability of the uppermost mantle along mid-ocean ridges. Earth Planet. Sci. Lett. 69, 88-106. doi: 10.1016/0012-821X(84)90076-90071

Dick, H. J. B., Natland, J. H., Alt, J. C., Bach, W., Bideau, D., Gee, J. S., et al. (2000). A long in situ section of the lower ocean crust: results of ODP Leg 176 drilling at the Southwest Indian Ridge. Earth Planet. Sci. Lett. 179, 31-51. doi: 10.1016/S0012-821X(00)00102-103

Dick, H. J. B., Natland, J. H., and Miller, D. J. (1999). Proceedings. ODP, Initial Reports. College Station, TX: Ocean Drilling Program.

Dick, H. J. B., Ozawa, K., Meyer, P. S., Niu, Y., Robinson, P. T., Constantin, M., et al. (2002). "'Primary silicate mineral chemistry of a $1.5-\mathrm{km}$ section of very slow spreading lower ocean crust: ODP Hole 735B, Southwest Indian Ridge," in Proceedings. ODP, Scientific Results, eds J. H. Natland, H. J. B. Dick, D. J. Miller, and V. Herzen, (College Station, TX: Ocean Drilling Program), 1-60.

Dick, H. J. B., Schouten, H., Meyer, P. S., Gallo, D. G., Bergh, H., Tyce, R., et al. (1991). "Tectonic evolution of the Atlantis II fracture zone," in Proceedings. ODP, Sci. Results, eds R. Von Herzen, and P. T. Robinson, (College Station, TX: Ocean Drilling Program).

Escrig, S., Capmas, F., Dupré, B., and Allègre, C. J. (2004). Osmium isotopic constraints on the nature of the DUPAL anomaly from Indian mid-ocean-ridge basalts. Nature 431, 59-63. doi: 10.1038/nature02904

Gale, A., Dalton, C. A., Langmuir, C. H., Su, Y., and Schilling, J.-G. (2013). The mean composition of ocean ridge basalts. Geochem.Geophys.Geosyst. 14, 489-518. doi: 10.1029/2012GC004334

Gao, Y., Hoefs, J., Hellebrand, E., von der Handt, A., and Snow, J. E. (2007). Trace element zoning in pyroxenes from ODP Hole 735B gabbros: diffusive exchange or synkinematic crystal fractionation? Contrib. Mineral. Petrol. 153, 429-442. doi: 10.1007/s00410-006-0158-154

Gao, Y., Hoefs, J., Przybilla, R., and Snow, J. E. (2006). A complete oxygen isotope profile through the lower oceanic crust. ODP Hole 735B. Chem. Geol. 233, 217-234. doi: 10.1016/j.chemgeo.2006.03.005

Goldberg, T., Gordon, G., Izon, G., Archer, C., Pearce, C. R., McManus, J., et al. (2013). Resolution of inter-laboratory discrepancies in Mo isotope data: an intercalibration. J. Anal. At. Spectrom. 28, 724-735. doi: 10.1039/C3JA30375F

Hamelin, B., Dupré, B., and Allègre, C. J. (1986). PbSrNd isotopic data of Indian Ocean ridges: new evidence of large-scale mapping of mantle heterogeneities. Earth Planet. Sci. Lett. 76, 288-298. doi: 10.1016/0012-821X(86)90080-90084

Hart, S. R., Blusztajn, J., Dick, H. J. B., Meyer, P. S., and Muehlenbachs, K. (1999). The fingerprint of seawater circulation in a 500-meter section of ocean crust gabbros. Geochim. Cosmochim. Acta 63, 4059-4080. doi: 10.1016/S00167037(99)00309-309
Hekinian, R., and Walker, D. (1987). Diversity and spatial zonation of volcanic rocks from the East Pacific Rise near $21^{\circ}$ N. Contrib. Mineral. Petrol. 96, 265-280. doi: 10.1007/BF00371248

Herzberg, C. (2004). Geodynamic information in peridotite petrology. J Petrol 45, 2507-2530. doi: 10.1093/petrology/egh039

Hill, E., Wood, B. J., and Blundy, J. D. (2000). The effect of Ca-Tschermaks component on trace element partitioning between clinopyroxene and silicate melt. Lithos 53, 203-215. doi: 10.1016/S0024-4937(00)00025-26

Hofmann, A. W. (1997). Mantle geochemistry: the message from oceanic volcanism. Nature 385:219. doi: 10.1038/385219a0

Hofmann, A. W. (2007). "2.03 - Sampling mantle heterogeneity through oceanic basalts: isotopes and trace elements," in Treatise on Geochemistry, eds H. D. Holland, and K. K. Turekian, (Oxford: Pergamon), 1-44. doi: 10.1016/b0-08043751-6/02123-X

Holm, P. M. (2002). Sr, Nd and Pb isotopic composition of in situ lower crust at the Southwest Indian Ridge: results from ODP Leg 176. Chem. Geol. 184, 195-216. doi: 10.1016/S0009-2541(01)00364-363

Jacobsen, S. B., and Wasserburg, G. J. (1984). Sm-Nd isotopic evolution of chondrites and achondrites. II. Earth Planet. Sci. Lett. 67, 137-150. doi: 10.1016/ 0012-821X(84)90109-2

Jenner, F. E., and O'Neill, H. S. C. (2012). Major and trace analysis of basaltic glasses by laser-ablation ICP-MS. Geochem.Geophys.Geosyst. 13:Q03003. doi: $10.1029 / 2011$ gc003890

John, B. E., Foster, D. A., Murphy, J. M., Cheadle, M. J., Baines, A. G., Fanning, C. M., et al. (2004). Determining the cooling history of in situ lower oceanic crust-Atlantis Bank. SW Indian Ridge. Earth Planet. Sci. Lett. 222, 145-160. doi: 10.1016/j.epsl.2004.02.014

Johnson, K. T. M., and Dick, H. J. B. (1992). Open system melting and temporal and spatial variation of peridotite and basalt at the Atlantis II Fracture Zone. J. Geophys. Res.: Solid Earth 97, 9219-9241. doi: 10.1029/92jb00701

Kamenetsky, V. S., Eggins, S. M., Crawford, A. J., Green, D. H., Gasparon, M., and Falloon, T. J. (1998). Calcic melt inclusions in primitive olivine at $43^{\circ} \mathrm{N}$ MAR: evidence for melt-rock reaction/melting involving clinopyroxene-rich lithologies during MORB generation. Earth Planet. Sci. Lett 160, 115-132. doi: $10.1016 /$ s0012-821x(98)00090-9

Kempton, P. D., Hawkesworth, C. J., and Fowler, M. (1991). "Geochemistry and isotopic composition of gabbros from layer 3 of the Indian Ocean crust, Hole 735B," in Proceedings ODP, Science Results, eds R. Von Herzen, and P. T. Robinson, (College Station, TX: Ocean Drilling Program), 127-143.

Kerr, R. C. (1995). Convective crystal dissolution. Contrib. Mineral. Petrol. 121, 237-246. doi: 10.1007/bf02688239

Klein, E. M. (2003). "3.13 - Geochemistry of the Igneous Oceanic Crust,” in Treatise on Geochemistry, eds H. D. Holland, and K. K. Turekian, (Oxford: Pergamon), 433-463. doi: 10.1016/b0-08-043751-6/03030-9

Klein, E. M., and Langmuir, C. H. (1987). Global correlations of ocean ridge basalt chemistry with axial depth and crustal thickness. J. Geophys. Res.: Solid Earth 92, 8089-8115. doi: 10.1029/JB092iB08p08089

Kvassnes, A. (2004). The Evolution of Oceanic Gabbros: In-situ and Ancient Examples.Cambridge, MA: MIT - Woods Hole Joint Program in Oceanography.

Lambart, S., Koornneef, J. M., Millet, M.-A., Davies, G. R., Cook, M., and Lissenberg, C. J. (2019). Highly heterogeneous depleted mantle recorded in the lower oceanic crust. Nat. Geosci.. 12, 482-486. doi: 10.1038/s41561-019-0368369

Langmuir, C. H., and Hanson, G. N. (1980). An evaluation of major element heterogeneity in the mantle sources of basalts. Philos. Trans. R. Soc. Lon.. Ser. A Math. Phys. Sci. 297, 383-407. doi: 10.1098/rsta.1980.0223

Lissenberg, C. J., and Dick, H. J. B. (2008). Melt-rock reaction in the lower oceanic crust and its implications for the genesis of mid-ocean ridge basalt. Earth Planet. Sci. Lett. 271, 311-325. doi: 10.1016/j.epsl.2008.04.023

Lissenberg, C. J., and MacLeod, C. J. (2016). A reactive porous flow control on mid-ocean ridge magmatic evolution. J. Petrol. 57, 2195-2220. doi: 10.1093/ petrology/egw074

Lissenberg, C. J., MacLeod, C. J., Howard, K. A., and Godard, M. (2013). Pervasive reactive melt migration through fast-spreading lower oceanic crust (Hess Deep, equatorial Pacific Ocean). Earth Planet. Sci. Lett. 361, 436-447. doi: 10.1016/j. epsl.2012.11.012 
Ludwig, K. R. (2008) Isoplot 3.71, 3.71. Berkeley, CA: Berkeley Geochronology Centre.

Lundstrom, C. C., Chaussidon, M., Hsui, A. T., P., and M. (2005). Observations of $\mathrm{Li}$ isotopic variations in the trinity ophiolite: evidence for isotopic fractionation by diffusion during mantle melting. Geochim. Cosmochim. Acta 69, 735-751. doi: 10.1016/j.gca.2004.08.004

Maaløe, S. (2011). Olivine phenocryst growth in hawaiian tholeiites: evidence for supercooling. J Petrol. 52, 1579-1589. doi: 10.1093/petrology/egr015

Mann, M. M., and DeShazer, L. G. (1970). Energy levels and spectral broadening of neodymium ions in laser glass. J. f Appl. Phys. 41, 2951-2957. doi: 10.1063/1. 1659342

McCoy-West, A. J., Millet, M.-A., Nowell, G. M., Nebel, O., and Burton, K. W. (2020). Simultaneous measurement of neodymium stable and radiogenic isotopes from a single aliquot using a double spike. J. Ana. At. Spectrom. 35, 388-402. doi: 10.1039/C9JA00308H

McCoy-West, A. J., Bennett, V. C., O’Neill, H. S. C., Hermann, J., and Puchtel, I. S. (2015). The interplay between melting, refertilization and carbonatite metasomatism in off-cratonic lithospheric mantle under Zealandia: an integrated major, trace and platinum group element study. J. Petrol. 56, 563-604. doi: 10.1093/petrology/egv011

McCoy-West, A. J., Bennett, V. C., Puchtel, I. S., and Walker, R. J. (2013). Extreme persistence of cratonic lithosphere in the Southwest Pacific: paleoproterozoic os isotopic signatures of Zealandia. Geology 41, 231-234. doi: 10.1130/ G33626.1

McCoy-West, A. J., Chowdhury, P., Burton, K. W., Sossi, P., Nowell, G. M., Fitton, J. G., et al. (2019). Extensive crustal extraction in Earth's early history inferred from molybdenum isotopes. Nat. Geosci. 12, 946-951. doi: 10.1038/s41561-0190451- 452

McCoy-West, A. J., Godfrey Fitton, J., Pons, M.-L., Inglis, E. C., and Williams, H. M. (2018). The Fe and $\mathrm{Zn}$ isotope composition of deep mantle source regions: insights from Baffin Island picrites. Geoch.et Cosmochim. Acta 238, 542-562. doi: 10.1016/j.gca.2018.07.021

McCoy-West, A. J., Millet, M.-A., and Burton, K. W. (2017). The neodymium stable isotope composition of the silicate Earth and chondrites. Earth Planet. Sci. Lett. 480, 121-132. doi: 10.1016/j.epsl.2017.10.004

McKenzie, D., and Bickle, M. J. (1988). The volume and composition of melt generated by extension of the lithosphere. J. Petrol. 29, 625-679. doi: 10.1038/ nature 12292

Meyer, P. S., Dick, H. J. B., and Thompson, G. (1989). Cumulate gabbros from the Southwest Indian Ridge, $54^{\circ} \mathrm{S}-7^{\circ} 16^{\prime} \mathrm{E}$ : implications for magmatic processes at a slow spreading ridge. Contrib. Mineral. Petrol. 103, 44-63. doi: 10.1007/ BF00371364

Meyzen, C. M., Ludden, J. N., Humler, E., Luais, B., Toplis, M. J., Mével, C., et al. (2005). New insights into the origin and distribution of the DUPAL isotope anomaly in the Indian Ocean mantle from MORB of the Southwest Indian Ridge. Geochem.Geophys. Geosyst. 6, doi: 10.1029/2005GC00 0979

Michael, P. J., and Cornell, W. C. (1998). Influence of spreading rate and magma supply on crystallization and assimilation beneath mid-ocean ridges: evidence from chlorine and major element chemistry of mid-ocean ridge basalts. J. Geophys. Res.103, 18325-18356. doi: 10.1029/98JB00791

Millet, M.-A., and Dauphas, N. (2014). Ultra-precise titanium stable isotope measurements by double-spike high resolution MC-ICP-MS. J. Anal. At. Spectrom 29, 1444-1458. doi: 10.1039/C4JA00096J

Millet, M.-A., Dauphas, N., Greber, N. D., Burton, K. W., Dale, C. W., Debret, B., et al. (2016). Titanium stable isotope investigation of magmatic processes on the Earth and Moon. Earth Planet. Sci. Lett. 449, 197-205. doi: 10.1016/j.epsl.2016. 05.039

Muller, M. R., Robinson, C. J., Minshull, T. A., White, R. S., and Bickle, M. J. (1997). Thin crust beneath ocean drilling program borehole $735 \mathrm{~B}$ at the Southwest Indian Ridge? Earth Planet. Sci. Lett. 148, 93-107. doi: 10.1016/S0012-821X(97) 00030-37

Natland, J. H., and Dick, H. J. B. (2001). Formation of the lower ocean crust and the crystallization of gabbroic cumulates at a very slowly spreading ridge. J. Volcanol. Geothermal Res. 110, 191-233. doi: 10.1016/S0377-0273(01)0021 1-216

Neely, R. A., Gislason, S. R., Ólafsson, M., McCoy-West, A. J., Pearce, C. R., and Burton, K. W. (2018). Molybdenum isotope behaviour in groundwaters and terrestrial hydrothermal systems. Iceland. Earth Planet. Sci. Lett. 486, 108-118. doi: 10.1016/j.epsl.2017.11.053

Nielsen, S. G., Horner, T. J., Pryer, H. V., Blusztajn, J., Shu, Y., Kurz, M. D., et al. (2018). Barium isotope evidence for pervasive sediment recycling in the upper mantle. Sci. Adv. 4, eaas8675. doi: 10.1126/sciadv.aas 8675

Niu, Y., Gilmore, T., Mackie, S., Greig, A., and Bach, W. (2002). "Mineral chemistry, whole-rock compositions, and petrogenesis of Leg 176 gabbros: Data and discussion," in Proceedings. ODP, Scientific Results, eds J. H. Natland, H. J. B. Dick, D. J. Miller, and R. P. Von Herzen, (College Station, TX: Ocean Drilling Program), 1-60.

O'Hara, M. J. (1968). Are ocean floor basalts primary magma? Nature 220:683. doi: $10.1038 / 220683 \mathrm{a} 0$

O'Hara, M. J. (1977). Geochemical evolution during fractional crystallisation of a periodically refilled magma chamber. Nature 266:503. doi: 10.1038/266503a0

O'Neill, H. S. C., and Jenner, F. E. (2012). The global pattern of trace-element distributions in ocean floor basalts. Nature 491, 698. doi: 10.1038/nature11678

Orlando, A., D'Orazio, M., Armienti, P., and Borrini, D. (2008). Experimental determination of plagioclase and clinopyroxene crystal growth rates in an anhydrous trachybasalt from Mt Etna (Italy). Eur. J. Mineral. 20, 653-664. doi: 10.1127/0935-1221/2008/0020-1841

Ponader, C. W., and Brown, G. E. (1989). Rare earth elements in silicate glassmelt systems: i. effects of composition on the coordination environments of La, Gd, and Yb. Geochim. Cosmochim. Acta 53, 2893-2903. doi: 10.1016/0016-7037(89) 90166-X

Prinzhofer, A., and Allégre, C. J. (1985). Residual peridotites and the mechanisms of partial melting. Earth Planet. Sci. Lett. 74, 251-265. doi: 10.1016/0012-821x(85) 90025-1

Rao, K. J., Wong, J., and Weber, M. J. (1983). Bonding and structure of Nd3+ in BeF2 glass by XANES and EXAFS spectroscopy. J. Chem. Phys. 78, 6228-6237. doi: 10.1063/1.444587

Regelous, M., Weinzierl, C. G., and Haase, K. M. (2016). Controls on melting at spreading ridges from correlated abyssal peridotite - mid-ocean ridge basalt compositions. Earth Planet.ry Sci. Lett. 449, 1-11. doi: 10.1016/j.epsl.2016. 05.017

Rehkämper, M., and Hofmann, A. W. (1997). Recycled ocean crust and sediment in Indian Ocean MORB. Earth Planet. Sci. Lett. 147, 93-106. doi: 10.1016/S0012821X(97)00009-5

Richter, F. M., Davis, A. M., DePaolo, D. J., and Watson, E. B. (2003). Isotope fractionation by chemical diffusion between molten basalt and rhyolite. Geochim. Cosmochim. Acta 67, 3905-3923. doi: 10.1016/S0016-7037(03)0017 4-171

Richter, F. M., Watson, E. B., Mendybaev, R., Dauphas, N., Georg, B., Watkins, J., et al. (2009). Isotopic fractionation of the major elements of molten basalt by chemical and thermal diffusion. Geochim. Cosmochim. Acta 73, 4250-4263. doi: 10.1016/j.gca.2009.04.011

Robinson, C. C. (1971). Evidence of sixfold coordination of $\mathrm{Nd} 3+$ in barium rubidium silicate glass. J. Chem. Phys. 54, 3572-3578. doi: 10.1063/1.1675383

Robinson, C. J., Bickle, M. J., Minshull, T. A., White, R. S., and Nichols, A. R. L. (2001). Low degree melting under the Southwest Indian Ridge: the roles of mantle temperature, conductive cooling and wet melting. Earth Planet. Sci. Lett. 188, 383-398. doi: 10.1016/S0012-821X(01)00329-326

Ross, K., Kamber, B. S., and McDonald, A. M. (2013). An empirical test of the crystal lattice strain model for rare-earth element partitioning into clinopyroxene. Chem. Geol. 340, 139-150. doi: 10.1016/j.chemgeo.2012.11.006

Rouxel, O., Dobbek, N., Ludden, J., and Fouquet, Y. (2003). Iron isotope fractionation during oceanic crust alteration. Chem. Geol. 202, 155-182. doi: 10.1016/j.chemgeo.2003.08.011

Ryan, W. B. F., Carbotte, S. M., Coplan, J. O., O’Hara, S., Melkonian, A., Arko, R., et al. (2009). Global multi-Resolution topography synthesis. Geochem. Geophys., Geosyst. 10:Q03014. doi: 10.1029/2008gc002332

Salters, V. J. M. (1996). The generation of mid-ocean ridge basalts from the Hf and Nd isotope perspective. Earth Planet. Sci. Lett. 141, 109-123. doi: 10.1016/0012821X(96)00070-72

Salters, V. J. M., and Stracke, A. (2004). Composition of the depleted mantle. Geochem.Geophys.Geosyst. 5:Q05B07. doi: 10.1029/2003GC000597

Schauble, E. A. (2004). Applying Stable Isotope Fractionation Theory to New Systems. Rev. Mineral.Geochem. 55, 65-111. doi: 10.2138/gsrmg.55.1.65 
Schiano, P., Birck, J.-L., and Allègre, C. J. (1997). Osmium-strontium-neodymiumlead isotopic covariations in mid-ocean ridge basalt glasses and the heterogeneity of the upper mantle. Earth Planet. Sci. Lett. 150, 363-379. doi: 10.1016/S0012-821X(97)00098-98

Shannon, R. (1976). Revised effective ionic radii and systematic studies of interatomic distances in halides and chalcogenides. Acta Crystallogr. Section A 32, 751-767. doi: 10.1107/S0567739476 001551

Sinton, J. M., and Detrick, R. S. (1992). Mid-ocean ridge magma chambers. J. Geophys. Res.: Solid Earth 97, 197-216. doi: 10.1029/91JB02508

Sio, C. K. I., Dauphas, N., Teng, F.-Z., Chaussidon, M., Helz, R. T., and Roskosz, M. (2013). Discerning crystal growth from diffusion profiles in zoned olivine by in situ Mg-Fe isotopic analyses. Geochim. Cosmochim. Acta 123(Suppl. C), 302-321. doi: 10.1016/j.gca.2013.06.008

Sossi, P. A., Foden, J. D., and Halverson, G. P. (2012). Redox-controlled iron isotope fractionation during magmatic differentiation: an example from the Red Hill intrusion. S. Tasmania. Contrib. Mineral. Petrol. 164, 757-772. doi: 10.1007/s00410-012-0769-x

Spivack, A. J., and Edmond, J. M. (1987). Boron isotope exchange between seawater and the oceanic crust. Geochim. Cosmochim. Acta 51, 1033-1043. doi: 10.1016/ 0016-7037(87)90198-90190

Staudigel, H., Hart, S. R., and Richardson, S. H. (1981). Alteration of the oceanic crust: processes and timing. Earth Planet. Sci. Lett. 52, 311-327. doi: 10.1016/ 0012-821X(81)90186-90182

Stracke, A., Hofmann, A. W., and Hart, S. R. (2005). FOZO, HIMU, and the rest of the mantle zoo. Geochem. Geophys. Geosyst. 6:Q05007. doi: 10.1029/ 2004GC000824

Sun, C., Graff, M., and Liang, Y. (2017). Trace element partitioning between plagioclase and silicate melt: the importance of temperature and plagioclase composition, with implications for terrestrial and lunar magmatism. Geochim. Cosmochim. Acta 206, 273-295. doi: 10.1016/j.gca.2017. 03.003

Teng, F.-Z., Dauphas, N., Huang, S., and Marty, B. (2013). Iron isotopic systematics of oceanic basalts. Geochim. Cosmochim. Acta 107, 12-26. doi: 10.1016/j.gca. 2012.12.027

Tepley, F. J., Lundstrom, C. C., McDonough, W. F., and Thompson, A. (2010). Trace element partitioning between high-An plagioclase and basaltic to basaltic andesite melt at 1 atmosphere pressure. Lithos 118, 82-94. doi: 10.1016/j.lithos. 2010.04 .001

Urey, H. C. (1947). The thermodynamic properties of isotopic substances. J. $t$ Chem. Soc. 562-581. doi: 10.1039/JR9470000562

Van Orman, J. A., Grove, T. L., and Shimizu, N. (2001). Rare earth element diffusion in diopside: influence of temperature, pressure, and ionic radius, and an elastic model for diffusion in silicates. Contrib. Mineral. Petrol. 141, 687-703. doi: $10.1007 /$ s004100100269

Van Orman, J. A., Grove, T. L., and Shimizu, N. (2002). Diffusive fractionation of trace elements during production and transport of melt in Earth's upper mantle. Earth Planet. Sci. Lett. 198, 93-112. doi: 10.1016/S0012-821X(02)00492-2
Vanko, D. A., and Stakes, D. S. (1991). "“" Fluids in oceanic layer 3: evidence from veined rocks, Hole 735B, Southwest Indian Ridge," in Proceedings. ODP, Sci. Results, eds R. Von Herzen, and P. T. Robinson, (College Station, TX: Ocean Drilling Program), 181-215.

Warren, J. M., Shimizu, N., Sakaguchi, C., Dick, H. J. B., and Nakamura, E. (2009). An assessment of upper mantle heterogeneity based on abyssal peridotite isotopic compositions. J. Geophys. Res.: Solid Earth 114, doi: 10.1029/ 2008JB006186

Watkins, J. M., DePaolo, D. J., and Watson, E. B. (2017). "Chapter 4. kinetic fractionation of non-traditional stable isotopes by diffusion and crystal growth reactions," in Non-Traditional Stable Isotopes, eds F.-Z. Teng, N. Dauphas, and J. M. Watkins, (Chantilly, VA: The Mineralogical Society of America), 85-126.

Watson, E. B., and Müller, T. (2009). Non-equilibrium isotopic and elemental fractionation during diffusion-controlled crystal growth under static and dynamic conditions. Chem. Geol. 267, 111-124. doi: 10.1016/j.chemgeo.2008. 10.036

Weber, M. J., and Brawer, S. A. (1982). Comparison of optical spectra and computer-simulated structure of rare-earth-doped fluoroberyllate glasses. J. Non Cryst. Solids 52, 321-336. doi: 10.1016/0022-3093(82)90307-90306

Weyer, S., and Ionov, D. A. (2007). Partial melting and melt percolation in the mantle: the message from Fe isotopes. Earth and Planetary Science Letters 259, 119-133. doi: 10.1016/j.epsl.2007.04.033

White, W. M. (1985). Sources of oceanic basalts; radiogenic isotopic evidence. Geology 13, 115-118. doi: 10.1073/pnas.1719570115

White, W. M. (1993). 238U/204Pb in MORB and open system evolution of the depleted mantle. Earth Planet. Sci. Lett. 115, 211-226. doi: 10.1016/0012821X(93)90223-V

White, W. M., and Bryan, W. B. (1977). Sr-isotope. K, Rb, Cs, Sr, Ba, and rare-earth geochemistry of basalts from the FAMOUS area. GSA Bull. 88, 571-576.

Wood, B. J., and Blundy, J. D. (1997). A predictive model for rare earth element partitioning between clinopyroxene and anhydrous silicate melt. Contrib. Mineral. Petrol. 129, 166-181. doi: 10.1007/s004100050330

Workman, R. K., and Hart, S. R. (2005). Major and trace element composition of the depleted MORB mantle (DMM). Earth Planet. Sci. Lett. 231, 53-72. doi: $10.1016 /$ j.epsl.2004.12.005

Zindler, A., and Hart, S. R. (1986). Chemical geodynamics. Annu. Rev. Earth Planet. Sci. 14, 109-132. doi: 10.1016/0040-1951(82)90125-1

Conflict of Interest: The authors declare that the research was conducted in the absence of any commercial or financial relationships that could be construed as a potential conflict of interest.

Copyright (C) 2020 McCoy-West, Millet and Burton. This is an open-access article distributed under the terms of the Creative Commons Attribution License (CC BY). The use, distribution or reproduction in other forums is permitted, provided the original author(s) and the copyright owner(s) are credited and that the original publication in this journal is cited, in accordance with accepted academic practice. No use, distribution or reproduction is permitted which does not comply with these terms. 